\title{
TRANSFORMANDO A DIFERENÇA: AS MULHERES NA POLÍTICA.
}

\author{
MÍRIAM PILLAR GROSSI E SÔNIA MALHEIROS MIGUEL
}

\section{Introdução}

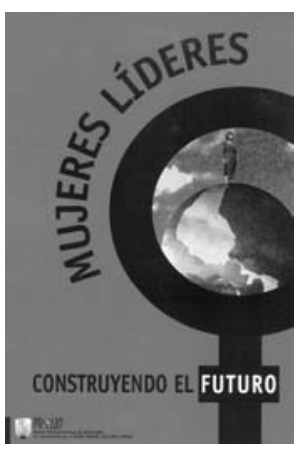

Este texto foi costurado a quatro mãos, tendo como linha as falas das participantes do Seminário Mulheres na Política - Mulheres no Poder, resgatadas das notas taquigráficas transcritas pelo Departamento de Taquigrafia, Revisão e Redação, da Câmara dos Deputados. É, portanto, em sua essência, um texto plural. Nele, as vozes de muitas mulheres, e de alguns homens, refletem sobre os desafios do "fazer e ser" no espaço da política.

O seminário teve como proposta avaliar as primeiras experiências com a política de cotas (implantada a partir das eleições de 1996) e pensar outras estratégias para o empoderamento' das mulheres. Entre seus objetivos salientamos: socializar as informações e reflexões referentes à temática mulher e poder, e difundir as experiências das mulheres em posição de poder; sensibilizar e articular as mulheres para a participação política; subsidiar as parlamentares para a realização de eventos regionais de apoio e estímulo às candidaturas de mulheres, e definir estratégias para ampliar a presença de mulheres em posições de poder. Organizado pelo

' Sobre a tradução do termo empowerment ver artigo de Magdalena Leon, "Empoderamiento: relaciones de las mujeres com el poder", publicado no Vol. 8 n. ${ }^{\circ}$ 2/2000, da REF. 
TRANSFORMANDO A DIFERENÇA: AS MULHERES NA POLÍTICA

CFEMEA - Centro Feminista de Estudos e Assessoria, ${ }^{2}$ Bancada Feminina no Congresso Nacional ${ }^{3}$ e CNDM - Conselho Nacional dos Direitos da Mulher, ${ }^{4}$ realizou-se em Brasília, na Câmara dos Deputados, de 16 a 18 de maio de $2000 .{ }^{5}$

O Seminário reuniu, durante três dias, cerca de 100 pessoas, entre parlamentares, prefeitas, pesquisadoras, mulheres candidatas às eleições municipais de 2000, representantes de Conselhos Estaduais e Municipais dos Direitos da Mulher, integrantes de núcleos e grupos de mulheres de partidos políticos, sindicatos e participantes dos movimentos de mulheres e feministas, numa rica conversa sobre os gostos e os desgostos da participação nos espaços de poder e da política.

Na abertura, duas manifestações: inicialmente um ato político no qual os partidos políticos, juntamente com as entidades responsáveis pelo seminário, se manifestaram sobre as políticas de cotas no contexto das ações afirmativas. $E$, logo após, um ato cultural, com o lançamento da cartiliha "Vereadora 2000, Agora são outros Quinhentos", de autoria da Deputada lara Bernardi, e do livro "A Política de Cotas por Sexo - um estudo das primeiras experiências no Legislativo brasileiro", publicado pelo CFEMEA.

Nas mesas de debates, senadoras, deputadas federais, deputadas estaduais e distritais, prefeitas e vereadoras revezaram-se no relato e reflexão sobre suas experiências no poder legislativo, pesquisadoras refletiram teoricamente sobre o tema e militantes feministas relataram suas ações para viabilizar o acesso das mulheres aos espaços de poder.

As mesas contaram, também, com a participação de representantes de dois organismos internacionais. Em exposição sobre o trabalho do UNIFEM, Branca Moreira Alves, falou dos esforços desenvolvidos pelo Fundo, em apoio ao fortalecimento das "redes temáticas" nas áreas de violência, direitos humanos e mulheres na política, contribuindo para que os movimentos de mulheres e femi-

${ }^{2}$ O CFEMEA é uma organização da sociedade civil, não-governamental, feminista, de caráter público e sem fins lucrativos. Tem sede em Brasília e é dirigido por um colegiado de mulheres. Foi criada em julho de 1989, com o objetivo de lutar pela plena cidadania das mulheres, por relações de gênero eqüitativas e solidárias, e por uma Sociedade e um Estado, justos e democráticos. (www.cfemea.org.br)

${ }^{3}$ Em maio de 2001, a Bancada Feminina do Congresso Nacional era composta por 5 Senadoras (PT - 3, PFL - 1 e PMDB - 1) e 35 Deputadas Federais (PMDB - 8, PSDB - 8, PT - 7, PFL - 6, PC do B - 4, PDT - 1 e PSB - 1). Em agosto de 1999 foi criada a Coordenação da Bancada Feminina, composta por 2 Deputadas Federais e uma Senadora, que passou a publicar, regularmente, o Boletim da Bancada, disponível em sites das parlamentares e no site do CFEMEA.

${ }^{4}$ O Conselho Nacional dos Direitos da Mulher - CNDM é um órgão colegiado, de caráter deliberativo, criado pela Lei n. ${ }^{0} 7.353$, de 29 de agosto de 1985, com a finalidade de promover, em âmbito nacional, políticas públicas voltadas para a eliminação de todas as formas de discriminação contra a mulher, assegurando-Ihe condições de liberdade e de igualdade de direitos, bem como sua plena participação nas atividades políticas, econômicas e sócio culturais do País. O CNDM está subordinado a Secretaria de Estado dos Direitos Humanos do Ministério da Justiça (www.mi.gov.br/sedh/cndm).

${ }^{5}$ Contou com o apoio, para sua realização do: IBAM - Instituto Brasileiro de Administração Municipal, UNALE - União Nacional dos Legislativos Estaduais, AMB - Articulação de Mulheres Brasileiras, REF - Revista Estudos Feministas, UNIFEM - Fundo de Desenvolvimento das Nações Unidas para a Mulher e do PROLID/BID - Programa de Apoio à Liderança e Representação da Mulher/Banco Interamericano de Desenvolvimento. 
MIRIAM PILLAR GROSSI E SÔNIA MALHEIROS MIGUEL

nista desenvolvam agendas próprias nos eventos promovidos pela ONU. Ana Lúcia Desolt expôs o trabalho do Banco Interamericano de Desenvolvimento - BID, apontando que, desde os anos 80, um dos eixos básicos do Banco é o fortalecimento da participação das mulheres nos postos de comando, tendo para isso criado o Programa de Apoio à Liderança e Representação da Mulher - PROLID.

\section{As cotas por sexo e o legislativo brasileiro}

Logo após a IV Conferência Mundial sobre a Mulher, ocorrida em setembro de 1995, em Beijing/China, a bancada feminina no Congresso Nacional, influenciada pelas experiências exitosas de outros países e pelo contexto dessa conferência, que teve entre os seus objetos de debates e resoluções a temática do acesso ao poder, se articula e propõe que se inclua, na legislação eleitoral brasileira, um artigo assegurando uma cota das vagas de cada partido ou coligação para as candidaturas de mulheres.

Em 29 de setembro de 1995, foi aprovada a Lei n. ${ }^{0} 9.100$, que estabeleceu as normas para a realização das eleições municipais do ano seguinte, e determinou uma cota mínima de $20 \%$ para as mulheres. ${ }^{6}$ Em 1997, após esta primeira experiência eleitoral com cotas, a Lei $n .{ }^{\circ} 9.504$, estende a medida para os demais cargos eleitos por voto proporcional - Câmara dos Deputados, Assembléias Legislativas Estaduais e Câmara Distrital - e altera o texto do artigo, assegurando, não mais uma cota mínima para as mulheres, mas uma cota mínima de 30\% e uma cota máxima de $70 \%$, para qualquer um dos sexos. ${ }^{7}$

As duas leis foram aprovadas pelo Congresso Nacional, recebendo também o apoio de grande parte da bancada masculina. Mas esse apoio teve de ser negociado e, junto com as cotas, os parlamentares aprovaram um aumento no número total de candidaturas que os partidos poderiam apresentar nos pleitos eleitorais, o que, na prática, resultou em uma diminuição do impacto da medida aprovada.

Inseridas no contexto mais amplo das ações afirmativas, a política de cotas é medida que visa alterar variados quadros de desigualdades - racial, étnica, sexual, social. As ações afirmativas reconhecem as discriminações existentes e agem no sentido de impedir que as mesmas se perpetuem. No caso das cotas eleitorais por sexo, esta ação afirmativa busca criar condições para o estabelecimento de um maior equilíbrio entre homens e mulheres no plano da representação política. Num primeiro momento, são medidas compensatórias que possibilitam que mais mulheres ocupem espaços. Num segundo, são medidas distributivas que buscam assegurar a igualdade entre homens e mulheres.

\footnotetext{
${ }^{6}$ Lei n. ${ }^{\circ} 9.100$ - Art. 11, § 3. Diário Oficial da União, de 02 de outubro de 1995.

${ }^{7}$ Lei n. 9.504 - Art. 10, § 30, Diário Oficial da União, de 01 de outubro de 1997. O artigo 80 das Disposições Transitórias definiu para as eleições de 1998, cota mínima de $25 \%$ e máxima de $75 \%$.
} 
TRANSFORMANDO A DIFERENÇA: AS MULHERES NA POLÍTICA

A aprovação da lei vem estimulando reflexões e ações da sociedade brasileira sobre a participação das mulheres nos espaços de poder, trazendo para a arena política o debate das formas de enfrentamento da questão. Nas eleições de 1996, a primeira no país com o sistema de cotas, parcerias entre a Bancada Feminina no Congresso Nacional, o IBAM - Instituto Brasileiro de Administração Municipal ${ }^{8}$ e organizações do movimento de mulheres, resultaram na campanha "Mulheres sem medo do Poder", que incluiu, além de uma cartilha que instrui as candidatas em suas campanhas, cursos de capacitação para mulheres candidatas, em diferentes regiões do país.

A Campanha de 1996, tendo como mote a lei de cotas, recém aprovada, deixou à mostra o potencial e a capacidade de articulação dos setores envolvidos - bancadas femininas, organizações não-governamentais e diferentes entidades do movimento de mulheres. Naquele ano, e nas campanhas eleitorais de 1998 e 2000, cresceram os seminários e encontros que tinham como proposta a capacitação das mulheres para as disputas eleitorais.

Procurando influir na quantidade e na qualidade da participação das mulheres na disputa e na prática política, esses esforços contribuem para a construção de novas posturas nos partidos políticos e no eleitorado. De forma ainda pequena, mas visível, aumenta a presença das mulheres nas disputas eleitorais. Nas eleições de 1998, pela primeira vez na história do Brasil, houve uma candidata à Presidência da República - de um partido pequeno. ${ }^{9}$ E, nas eleições de 2000, concorreram 70.321 mulheres às Câmaras de Vereadores e 1.139 às Prefeituras Municipais. Foram eleitas 6.992 vereadoras e 318 prefeitas. ${ }^{10}$ Destas, seis vão dirigir prefeituras de capitais, uma delas, a prefeitura da cidade de São Paulo, a maior do país."

Hoje, além da luta das mulheres pelo acesso ao poder legislativo, outras lutas por níveis de paridade começam a se fazer visíveis nos demais poderes constituintes do Estado: o Executivo e o Judiciário. ${ }^{12}$ No bojo dessas novas reivin-

${ }^{8} \mathrm{O}$ IBAM é uma organização não-governamental que se dedica há mais de 40 anos ao aperfeiçoamento dos governos municipais e suas relações com a sociedade civil. Na sua estrutura possui o Núcleo de Estudos Mulher e Políticas Públicas (www. ibam.org.br/des/mulher/mulher.htm)

${ }^{9}$ Thereza Ruiz, candidata do PTN - Partido Trabalhista Nacional, concorreu com outros 11 candidatos.

${ }^{10}$ Ver em anexo quadro com as estatísticas eleitorais de 2000, com número e porcentagem de mulheres e homens, candidat@s e eleit@s para as Câmaras de Vereadores e Prefeituras Municipais, por unidade da federação e por partido político.

${ }^{11}$ As mulheres eleitas para governarem capitais foram: Kátia Born Ribeiro (PSB) - Maceió/AL; Wilma Maria de Faria Meira (PSB) - Natal/RN; Maria Teresa Saenz Surita Jucá (PSDB) - Boa Vista/RR; Angela Regina Heinzen Amin Helou (PPB) Florianópolis/SC; Marta Teresa Suplicy (PT) - São Paulo/SP; e Nilmar Gavino Ruiz (PFL) - Palmas/TO.

${ }^{12}$ Segundo dados do CFEMEA, em janeiro de 2001, tramitavam, no Congresso Nacional, 13 proposições legislativas sugerindo medidas de ação afirmativa na busca de uma maior equidade entre mulheres e homens, em diferentes instâncias de decisão e representação políticas, entre elas: cotas por sexo ou alternância de sexo nas listas de indicações para os altos cargos do judiciário e executivo; estabelecimento de listas de candidaturas para as eleições proporcionais; e ampliação da cota estabelecida. E, estas iniciativas se espalham pelos Estados. Em janeiro de 1999 foi sancionada a Lei n. ${ }^{\circ} 11303$, que estabeleceu cotas por sexo no preenchimento dos órgãos colegiados da administração direta e indireta do Estado do Rio Grande do Sul. A Lei aprovada, originou-se de projeto apresentado pela deputada estadual Maria do Carmo Bueno (PPB/RS). Em março de 2001, a deputada estadual Iraê Lucena (PMDB/PB), apresentou um projeto de lei propondo cotas por sexo no provimento de cargos de direção dos órgãos subordinados a administração de seu Estado. 
MIRIAM PILLAR GROSSI E SÔNIA MALHEIROS MIGUEL

dicações de paridade, também se encontram as lutas pelo acesso igual das mulheres a cargos de chefia no serviço público, assim como políticas afirmativas em grandes empresas (sobretudo multinacionais), em busca da valorização das mulheres e de características consideradas como "femininas" (subjetividade, emoção, capacidade relacional, etc.), pois essas contribuiriam para melhores relações e rendimento no trabalho.

No âmbito dos movimentos sociais, também ocorreram iniciativas no sentido de se implantar as cotas por sexo nas regras para a composição de suas instâncias de direção, garantido-as nos estatutos das entidades. Assim, a Central Única dos Trabalhadores (CUT), a Força Sindical, a Confederação Geral de TrabaIhadores (CGT) e a Confederação Nacional dos Trabalhadores da Agricultura (CONTAG), bem como a União Nacional dos Estudantes (UNE) e a União Brasileira dos Estudantes Secundaristas (UBES) adotam dispositivos visando a redistribuição de poder político entre homens e mulheres, colocando limites mínimo e máximo, de $30 \%$ e $70 \%$ respectivamente, para ambos os sexos, para a ocupação dos cargos de direção desses órgãos. ${ }^{13}$

Nos últimos anos, crescem as reflexões, articulações e manifestações do movimento de mulheres e feministas, em torno da questão do acesso ao poder e do chamado empoderamento das mulheres. Essa também vem sendo a postura da bancada feminina no Congresso Nacional que, recorrentemente, articulada com diferentes organizações de mulheres, vem realizando ações com o objetivo de incentivar a participação de mais mulheres no âmbito do legislativo e nos demais espaços de poder. As parlamentares eleitas e as feministas militantes de partidos políticos têm influenciado seus partidos na criação de núcleos, coordenações ou articulações de mulheres, ao mesmo tempo em que têm contribuído para a introdução da política de cotas em algumas das direções partidárias. ${ }^{14}$

\section{O Seminário}

O Seminário Mulheres na Política - Mulheres no Poder foi mais uma dessas iniciativas na busca de alterações, quantitativas e qualitativas, no quadro de representação feminina nos diferentes espaços legislativos. No ano 2000, a disputa de 60.277 vagas paras as Câmaras de Vereadores e 5.559 vagas para as Prefeituras Municipais, mobilizou de norte a sul, o País. Dessas disputas participaram 71.460 mulheres, inscritas em algum dos 30 partidos políticos que disputaram o pleito.

O seminário ocorreu nesse contexto e fez parte de um leque de manifestações, capitaneadas por mulheres inseridas em sindicatos, partidos, universidades e outros movimentos, no sentido de utilizar o processo eleitoral para a dissemina-

\footnotetext{
${ }^{13}$ Rodrigues, Almira. "Mulheres: Movimentos Sociais e Partidos Políticos", texto disponível no site do Cfemea. 14 Segundo levantamento realizado pelo CFEMEA, 4 partidos adotaram cotas ou alguma outra medida de ação afirmativa na composição de suas direções (PT, PPS, PV, PDT ); e 13 deles possuem núcleos, coordenações ou articulações de mulheres (PCO, PDT, PFL, PL, PPB, PPS, PSB, PSDB, PSDC, PSTU, PT, PTB, PT do B).
} 
TRANSFORMANDO A DIFERENÇA: AS MULHERES NA POLÍTICA

Ção de suas idéias e plataformas. ${ }^{15} \mathrm{Na}$ Bahia, a Campanha pela Valorização da Mulher Negra na Política ${ }^{16}$ e o Il Encontro sobre Mulher e Política na Bahia ${ }^{17}$. Em São Paulo, o seminário Mulheres em Campanha e o Encontro Gênero e Políticas Públicas. ${ }^{18}$ Em diversas unidades da federação, os encontros organizados por mutheres de diferentes grupos e partidos políticos são exemplos das formas pelas quais o movimento de mulheres e feminista vem se apropriando dos momentos eleitorais.

As mulheres vêm percebendo, também, a importância e a necessidade de um apoio permanente às eleitas, e já é comum, após as eleições, a realização de encontros reunindo as mulheres eleitas, com o objetivo de trocar experiências e qualificá-las para o desempenho de suas funções, a exemplo do Seminário Nacional de Mulheres do PSB, organizado pela Secretaria Nacional de Mulheres do PSB; ${ }^{19}$ do $1^{\circ}$ Encontro Nacional de Deputadas Estaduais, promovido pela Secretaria de Mulheres da UNALE; 20 e do Seminário "Formação Política de Mulheres para Atuação Igualitária nas Instâncias Decisórias nos municípios Goianos", promovido pelo Núcleo de Investigação de Gênero, da Universidade de Goiás, que reuniu as prefeitas e vereadoras eleitas em Goiás. ${ }^{21}$

Três foram as principais temáticas propostas pela programação do seminário: a participação política das mulheres, a validade das cotas e a questão do poder. Mas, nos chamou a atenção uma temática não prevista na pauta: a das formas das mulheres conciliarem carreira política com vida privada, que ocupou parte significativa dos depoimentos, particularmente nos momentos dos debates. Também foi significativa a tomada de posição de grande parte dos participantes sobre a possibilidade de as mulheres fazerem uma política diferente, marcada pela sensibilidade feminina. Em alguns momentos, a reflexão dava espaço para discursos políticos afirmativos, em outros, as provocações da mesa remexiam em histórias pessoais que eram compartilhadas com a plenária.

Na abertura do Seminário, ${ }^{22}$ presidentes e representantes de vários Partidos

\footnotetext{
${ }^{15}$ Nas eleições de 2000, a Articulação de Mulheres Brasileiras, a Rede Nacional Feminista de Saúde e Direitos Reprodutivos, o Fórum de Mulheres do Distrito Federal, para citar alguns exemplos, lançaram "plataformas feministas", com reivindicações e propostas do movimento de mulheres, para homens e mulheres candidatas.

${ }^{16}$ Uma promoção do "Ya Mim - Coletivo de Mulheres Negras da Bahia", que contou com o apoio do CESE - CNDM/ AMB - FASE/RJ.

${ }_{17}$ Promovido pelo Núcleo de Estudos Interdisciplinares sobre Mulher e pela Comissão Especial de Defesa dos Direitos da Mulher da Assembléia Legislativa da Bahia.

${ }^{18}$ O primeiro, foi realizado pelo Conselho Estadual da Condição Feminina e pela organização Elas por Elas na Política, com o apoio da Câmara Municipal de São Paulo; e o segundo, foi promovido pelo Instituto Polis.

19 Realizado em Brasília, em março de 2001.

${ }^{20}$ O Encontro aconteceu nos dias 29 a 31 de março, em Cuiabá.

${ }^{21}$ O Seminário aconteceu em abril de 2001 e foi organizado pelo Núcleo de Investigação de Gênero/Programa Interdisciplinar da Mulher, Estudos e Pesquisas - PIMEP, da Universidade de Goiás

${ }^{22}$ Constavam da mesa de abertura: Deputado Severino Cavalcanti, Segundo-Vice-Presidente da Mesa da Câmara dos Deputados; Deputada lara Bernardi, Coordenadora da Bancada Feminina no Congresso Nacional; Ministra do Superior Tribunal de Justiça Eliana Calmon; Senador Roberto Freire, Presidente Nacional do PPS; Deputado José Dirceu, Presidente Nacional do PT; Deputada Luiza Erundina, representando o Presidente Nacional do PSB; Deputado Fernando Coruja representando o presidente nacional do PDT; Sra. Ika Fleury, Presidente Nacional do PTB Mulher, representando o Presidente Nacional do PTB; Solange Bentes Jurema, Presidenta do Conselho Nacional dos Direitos da Mulher; e Almira Rodrigues, Diretora Colegiada do CFEMEA.
} 
MIRIAM PILLAR GROSSI E SÔNIA MALHEIROS MIGUEL

Políticos, com representação no Congresso Nacional, colocaram suas posições e visões sobre a presença das mulheres na vida política. Falas estas ilustrativas da crescente incorporação dos temas relativos à mulher nos discursos políticos: ${ }^{23}$

"Por isso, acho que a revolução na questão da mulher já aconteceu no sentido da ruptura. O espaço e a luta para consolidar essa revolução e melhorar a vida da sociedade ainda estamos devendo. As mulheres vão rapidamente - porque isso aconteceu nos últimos quarenta anos - tomar espaço de poder, esses espaços políticos, e sem dúvida nenhuma vão contribuir muito para a luta pela igualdade. As cotas (...) são uma discriminação positiva, feita em boa hora. Temos de fazer muitas discriminaçóes positivas para aqueles que, em determinado instante, por um ou outro fator, estão excluídos da sociedade, como foi a mulher, secular ou milenarmente. (Deputado Federal Fernando Coruja PDT/SC - representando o Presidente Nacional do PDT

"Como candidato à Presidência da Câmara, há no meu programa um tópico que fala sobre a participação da mulher na Mesa Diretora da Casa. Não há justificativa alguma para não termos uma representante da mulher na Mesa Diretora. Já existe no Senado Federal. E por que não teremos na Câmara dos Deputados? Temos valorosas companheiras Deputadas, que darão novo brilho à Mesa, se assim conseguirmos. Vejo a participação da mulher como um grande passo que se está dando na política brasileira. Aproveito a oportunidade para dizer da satisfação de estarmos neste conclave sobre valorização da mulher". (Deputado Federal Severino Cavalcante - PPB/PE - Segundo vice-presidente da Mesa da Câmara dos Deputados) ${ }^{24}$

"(...) a luta contra a discriminação de gênero tem dimensão cultural, econômica e política. Trata-se da mudança das relações entre as pessoas na sociedade e a valorização da mulher. No terreno econômico, a discriminação acentua-se na questão do emprego feminino. As mulheres sofrem discriminação quanto ao salário. A sua valorização, portanto, é a forma de conquistarem mais autonomia nas relações com os homens". (Deputado Federal Sérgio Miranda - PC do B/MG representando o Presidente Nacional do PC do B)

Como assinalamos em negrito, nas falas acima, a temática do seminário é reapropriada de diferentes formas, indicando como as diferentes categorias analíticas, construídas nos últimos 30 anos, tanto pelo movimento feminista quanto por pesquisadoras da área, são incorporadas diferentemente nos discursos políticos. Assim, vemos o termo mulher, que nos remete às lutas e à produção teórica dos anos 60/70 e o termo gênero, referenciado aos debates iniciados a partir dos anos 80 , no interior deste campo político/acadêmico.

\footnotetext{
${ }^{23}$ Todas as citações são retiradas das notas taquigráficas do seminário: BRASIL. Câmara dos Deputados. Notas taquigráficas do Seminário Mulheres na Política Mulheres no Poder. Brasília, 16 a 18 de maio de 2000. E todos os negritos são nossos.

${ }^{24}$ Severino Cavalcante era na época um dos candidatos à presidência da Câmara dos Deputados (não tendo sido eleito posteriormente). E, apesar do candidato eleito, Aécio Neves (PSDB), ter tido a preocupação de afirmar em seu discurso de posse (transmitido ao vivo pela TV Câmara) que incorporaria as mulheres na mesa diretora, a nova composição da mesa diretora da Câmara dos Deputados não inclui uma única mulher. O mesmo ocorreu no Senado Federal, com a eleição do senador Jader Barbalho (PMDB), onde também não há mulher na mesa diretora. Em 21 de fevereiro de 2001, a deputada Ana Corso (PT/RS) e o deputado Orlando Fantazzini (PT/SP) apresentaram o Projeto de Resolução n. ${ }^{\circ}$ 130/01 que altera o Regimento Interno da Câmara dos Deputados instituindo uma cota por sexo, mínima de 30\% e máxima de 70\%, para a Mesa Diretora.
} 
TRANSFORMANDO A DIFERENÇA: AS MULHERES NA POLÍTICA

Junto com estes termos mais abrangentes, são utilizados termos mais específicos que qualificam o lugar das mulheres, e a necessidade de equidade entre mulheres e homens. Partlclpação, presença, moblilzação, dlscriminação, exclusão, valorização, lgualdade, desigualdade são categorias que passam a ser utilizadas de maneira recorrente nos discursos políticos.

"Acredito que nunca foi tão necessária a presença da mulher na política, não só por questão de direito e igualdade, mas de sensibilidade. A mulher, que hoje já chefia quase um quarto das famílias brasileiras, precisa e deve, cada vez mais, participar da vida política. Quando falo em participar da vida política, não estou fazendo referência a apenas se filiar a um partido ou ser candidata a um cargo eletivo, mas principalmente - e acredito ser o principal problema do Brasil hoje participar da luta social e da política, de modo geral". (Deputado Federal José Dirceu - PT/SP - Presidente Nacional do PT)

Outros depoimentos assinalam as formas como seus partidos têm enfrentado o desafio de incorporar as mulheres em cargos de direção e estimulá-las a se candidatar, ao mesmo tempo em que lamentam esta falta nas diferentes instâncias partidárias:

"Trago a mensagem do Presidente do partido, camarada João Amazonas, que, sem dúvida, defende essa questão. No meu Estado, Minas Gerais, quem preside o partido é uma mulher, a Vereadora Jô Moraes, e quem preside o Comitê Municipal é também uma mulher."(Deputado Federal Sérgio Miranda - PC do B/MG - representando o Presidente Nacional do PC do B)

"Tenho a satisfação de estar representando o Partido Popular Socialista, lamentando apenas não poder ser representado por uma Parlamentar do nosso partido no âmbito federal. Temos candidatas à Prefeitura em algumas cidades, inclusive capitais, com chances efetivas de poderem ser anunciadas, se aqui estivessem, como futuras Prefeitas". (Senador Roberto Freire - PPS/ PE - Presidente Nacional do PPS)

Os discursos acima, produzidos por parlamentares homens, são também ditos pelas mulheres participantes do Seminário, mostrando que os temas da participação política das mulheres e do lugar das mulheres na sociedade brasileira vêm sendo apropriados, por mulheres e homens, a partir das mesmas fontes, indicando que neste caso, a tão requisitada relação entre os "estudos" e a "vida", parece estar acontecendo:

"Este seminário pretende ser mais um espaço para reflexão e atuação no sentido da construção das relações de igualdade entre mulheres e homens. Nesses dois dias, avaliaremos as experiências com a política de cotas para as mulheres nas eleições legislativas do Brasil e na América Latina, além de socializar as informações e reflexões referentes à área da mulher e do poder e difundir as experiências das mulheres em posição de poder". (Deputada Federal lara Bernardi - PT/SP - representando a Bancada Feminina no Congresso Nacional)

Os discursos da abertura, nos pareceram ilustrativos de uma preocupação, legítima e autêntica por parte dos partidos políticos brasileiros, de incorporar as 
MIRIAM PILLAR GROSSI E SÔNIA MALHEIROS MIGUEL

mulheres em suas fileiras e em instâncias de representação. Mas, no decorrer do seminário, foi possível constatar que as práticas político-partidárias ainda estão muito longe de refletir este ideário. Como pode ser constatado nas críticas feitas, durante o seminário, a respeito da forma como os partidos têm incorporado a luta das mulheres por maior representação política.

\section{Cotas e Partidos}

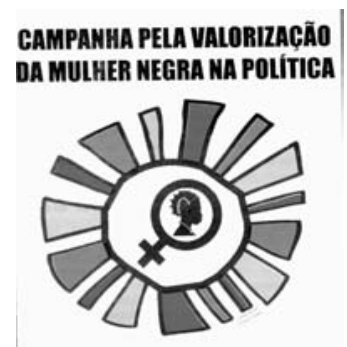

VOTE NEGRA. VOTE MULHER!

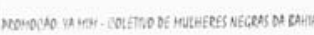
APO10: CESE - CNOM/AMB - FASE/RI

As avaliações das primeiras experiências com as políticas de cotas, expressas nas falas do seminário, são de dois tipos: um afirmativo da importância dessa política e outro que se interroga sobre sua efetividade. Para as primeiras, as cotas estariam proporcionando mais oportunidades para as mulheres, ao forçar os partidos políticos e, por conseguinte a sociedade em geral, a refletir sobre a ausência das mulheres na política. Para as segundas, as cotas não estariam surtindo o efeito desejado, pois para alguns cargos, teriam sido eleitas menos mulheres do que em anos anteriores. Nesta perspectiva as cotas estariam deixando de cumprir o seu objetivo primordial: eleger mais mulheres. A pergunta subjacente é: se, mesmo com a existência de cotas por sexo em muitos lugares as mulheres não conseguem ampliar o número de eleitas, qual seria o sentido da manutenção deste mecanismo?

"Exatamente no momento em que democratizou a sociedade, tenho de ter representações de todos os segmentos, não porque a mulher seja melhor ou pior, não porque ela seja diferente. É preciso termos consciência de que não somos diferentes, somos segmentos da sociedade e por isso mesmo somos diferentes só no momento em que queremos igualdade. Daí porque a política de cotas, que chamo de discriminação benigna ser uma discriminação favorável à mulher. A mulher se discrimina no momento em que faz uma política de cotas, mas esta discriminação é necessária, pela grande e secular desigualdade". (Eliana Calmon - Ministra do Superior Tribunal de Justiça)

"A política de cotas não veio para fazer com que as mulheres sejam vitoriosas nas eleições. Senti isso muito de perto em 1996. Estamos participando de eleições desde a década passada e já dá para fazer um histórico. O resultado é independente da política de cotas, pelo menos até agora (...).Somos 94 parlamentares em São Paulo. As mulheres já ocuparam 11 vagas. Hoje, somos oito (...). Fomos eleitas em 1998, com a política de cotas, já implantada. Por que, então, o resultado foi pior?". (Deputada Estadual Célia Leão - PSDB/SP)

Entre as explicações para esta ineficácia, foram invocadas duas questões: a resistência dos partidos e a dita "questão cultural", com a internalização, pelas próprias mulheres, de que o mundo político não seria o lugar delas. Entre as questões levantadas como "culturais", falou-se muito no medo masculino de que as mulheres passem a ocupar seus espaços e/ou "mandar neles", como bem ex- 


\section{TRANSFORMANDO A DIFERENÇA: AS MULHERES NA POLÍTICA}

pressou uma das presentes relatando o temor de um de seus eleitores caso ela viesse a ser prefeita:

"(...) na eleição passada quando fui candidata a Prefeita, um homem abordou-me e falou que votaria em mim todas as vezes que eu fosse candidata a Vereadora e a Deputada, mas à Prefeita, de jeito nenhum. Perguntei-lhe o porquê daquela decisão. Ele falou que, se uma mulher mandasse na cidade, sua esposa ia querer mandar nele dentro de casa (Risos)". (Deputada Federal Miriam Reid PDT/RJ)

Se, no exemplo acima, os homens explicitam seus temores em compartiIhar os espaços de poder, em outras falas fica evidente a ainda "rebeldia" das mulheres que ousam ter opiniões próprias, diferentes de seus maridos e pais, votando independentemente, como no exemplo abaixo:

"Um dia, num comício, uma senhora de quarenta e poucos anos, acompanhada de sua filha, de uns 20 anos, disse-me que na sua casa todas iam votar em mim, mas que o marido não sabia daquela decisão que haviam tomado. Isso para mim fol muito significativo. Estamos quase mudando de século e ainda há maridos que não podem saber que a mulher, a filha, a mãe e a sogra vão votar em uma mulher". (Deputada Estadual Célia Leão - PSDB/SP).

Várias parlamentares denunciavam a resistência dos partidos em apoiar suas candidaturas, mesmo que estas fossem as que mais tivessem chances eleitorais, mostrando que, nestes casos, o que prevalece não é a tão decantada lógica eleitoral - "quem tem chances de ganhar, tem sua candidatura apoiada pelo partido" - e sim a lógica sexista:

"As últimas pesquisas colocaram-nos em condições favoráveis, com mais de $30 \%$ da intenção de votos (...). No meu partido, depois de mim, que tenho $\mathbf{3 8 \%}$, há outro candidato com $2 \%$. Contudo, continua a briga para saber quem vai ser candidato. Pergunto-lhes: se fosse invertida a situação, haveria alguma discussão? Caso fossem $38 \%$ contra $15 \%$ - não estou nem dizendo $38 \%$ contra $2 \%$, ou $38 \%$ contra 20\% - haveria alguma discussão? Não". (Deputada Estadual Célia Leão - PSDB/SP)

"No meu caso, por exemplo, (...) não tinha outro concorrente, mas havia uma tendência dentro do partido de apolar um outro partido, uma outra candidatura. Quer dizer, como somos mulheres, podemos ficar um pouquinho para trás. Vocês sabem que existe um pouco disto na cabeça masculina. Temos de enfrentar isto cotidianamente em todos nossos ambientes. Inclusive, na Câmara Federal". (Deputada Federal Maria Elvira - PMDB/MG)

Nos dois casos acima, os testemunhos mostram que uma mulher candidata jamais consegue concorrer segundo as mesmas regras dos homens candidatos. No primeiro caso, o partido não reconhece a vantagem de $36 \%$ de intenções de voto para a candidata e no segundo, o partido, por não ter um candidato homem, prefere esvaziar a candidatura feminina, propondo alianças com outros partidos. É muito difícil tornar visível para os próprios partidos estas "escolhas" como sexistas, uma vez que nestes casos parecem sempre prevalecer outras regras do jogo político. 
MIRIAM PILLAR GROSSI E SÔNIA MALHEIROS MIGUEL

Como dificuldades encontradas pelas mulheres para uma maior participação na política, muitas das intervenções destacam a falta de apoio financeiro e de recursos materiais para as campanhas, colocando-as, também nesse momento, em situação de desvantagem em relação aos homens.

"Mas ainda temos muitas dificuldades a superar. É necessário que os partidos coloquem à disposição das mulheres os meios para que possam disputar em condições de igualdade. É preciso que se pratique, nos partidos e nas coligações, uma distribuição igualitária dos recursos financeiros e materiais. Será uma ação afirmativa no âmbito partidário tão importante para as mulheres como foi a inclusão do artigo " $a$ " nas cédulas eleitorais e na urna eletrônica, que permitiu às candidatas deixarem de ser vereador, senador e governador e passarem a ter seu gênero reconhecido" (Deputada Federal lara Bernardes - PT/SP)

O reconhecimento da "resistência dos partidos", não é exclusividade do olhar feminino, como atestam alguns depoimentos masculinos no seminário:

"É verdade - e as camaradas têm razão quando argumentam nos nossos fóruns internos - que não damos ainda valor suficiente à importância do trabalho das mulheres nas instâncias políticas". (Deputado Federal Sérgio Miranda PC do B/MG - representando o Presidente Nacional do PC do B)

O questionamento da sinceridade dos discursos em apoio à participação das mulheres e da debilidade dos apoios dados pelos partidos políticos às candidaturas de mulheres, também foi um tópico levantado:

"Será que o partido político vai fazer toda a força que deveria, para a mulher aparecer, crescer e ser eleita? (...) Os partidos ainda estão tímidos no seu trabalho de elevar, de valorizar e incentivar a mulher que já está filiada (...). Quanto à estrutura de campanha, a mulher está muito aquém. Os recursos são destinados em maior número para homens. Por quê? Porque ainda não se acredita na campanha da mulher, então se investe mais na campanha do homem. Essa é a realidade". (Deputada Estadual Célia Leão - PSDB/SP)

A incorporação de uma política de cotas nas estruturas partidárias, bem como uma capacitação dos quadros partidários, entre outras nas "questões de gênero", foram demandas levantadas:

"Temos também de dar poder para as mulheres na estrutura do próprio partido, dispondo de cotas nas direções executivas partidárias, fazer uma preparação didática dos quadros partidários nos institutos de estudo e pesquisa, quanto às questões de gênero. Já que se dá palestra de tantas coisas, nesses institutos de partidos, que também se fale da questão de gênero, que isso entre nas preparações didáticas partidárias; monitorar as candidatas inscritas pelo partido quanto à preparação, organização e articulação das campanhas femininas". (Solange Bentes - Presidenta do Conselho Nacional dos Direitos da Mulher)

"Também exigi, como mulher, falar em nome do PTB mulher, e digo que nossas companheiras estão, na sua grande maioria, aptas a enfrentar a guerra que surgirá pela frente (Palmas). Mas algumas ainda precisam de toda uma formação político-partidária. Infelizmente, a maioria dos nossos partidos deixou de dar esta formação política". (lka Fleury - Presidente Nacional do PTB Mulher) 
TRANSFORMANDO A DIFERENÇA: AS MULHERES NA POLÍTICA

A justificativa para a participação das mulheres na política, em muitas das falas vem associada ao reconhecimento de um valor ético, intrínseco às mulheres. Nesse entendimento, uma maior presença das mulheres nos espaços de poder resolveria, por si só, uma equação que associa poder = homem = corrupção.

"A pesquisa da Vox Popoli, da CNT, foi uma das coisas mais importantes que aconteceu nos últimos anos. Ficou claro que o povo está dando maior credibilidade, achando que a mulher é mais honesta, é mais eficiente (...) no geral a nossa imagem está em crescimento e somos a bola da vez". (Deputada Federal Maria Elvira - PMDB/MG)

Algumas das falas nos remetem para temas que o movimento feminista vem colocando há muitos anos, entre eles a "identidade feminina", o que faria com que a convivência entre mulheres de diferentes partidos fosse possível, ou menos complicada, do que com os homens de seus próprios partidos políticos:

"Tenho mais dificuldade de trabalhar em meu partido do que com mulheres. Com mulheres é muito mais fácil. Supra-partidariamente temos muito mais prazer em trabalhar do que dentro de um partido político, mesmo no meu, que se diz e busca ser democrático". Nereadora Eni Fernandes PT/São José do Rio Preto/ $S P]$

A incorporação da crítica feminista parece ser moeda corrente nos discursos das mulheres políticas, como nos depoimentos abaixo:

"A cota mínima para as candidaturas de mulheres nas chapas partidárias (...) fez com que o tema da mulher e poder saísse do círculo restrito dos temas feministas e passasse para a agenda política nacional". (Deputada Federal lara Bernardes - PT/SP)

A política de cotas, além de questionar homens e instituições partidárias, sobre o espaço que ocupam na política, coloca em cheque também o desejo das próprias mulheres. A queixa dos partidos - faltam mulheres para preencher as vagas asseguradas pelas cotas - faz com que se questionem sobre essa ausência, e sobre as formas de superá-las:

"Volta e meia me liga uma jornalista perguntando porque as mulheres não aparecem se será difícil preencher a cota no partido (...). É claro que temos que reconhecer que a lei de cotas foi um grande avanço, mas a questão passa muito pelo cultural; nós, mulheres, nunca fomos incentivadas a entrar na política. Esse sempre foi um terreno reservado para os homens (...). Ainda causamos certa confusão nos partidos políicos". (Deputada Federal Maria Elvira - PMDB/MG).

Essa história de dizer: 'Ah!, mas no nosso partido ficou vaga, vai faltar'. Então põem a 'laranja'. Põem a mexerica, põem a banana, põem o que quiser, mas as mulheres têm de participar. (Deputada Estadual Célia Leão - PSDB/SP)

"(...) Mesmo que ainda não tenhamos mulheres com capacidade de mobilização para ganhar voto, que elas ainda tenham dificuldade em admitir ser candidatas, espero que as mulheres e os partidos políticos tenham como responsabilidade o cumprimento 
MIRIAM PILLAR GROSSI E SÔNIA MALHEIROS MIGUEL

dessa cota (...). As mulheres têm de garantir que os homens não ocuparão as vagas a elas destinadas. Não há um trabalho de militância das nossas feministas no sentido de cobrir essa cota. (Senador Roberto Freire - PPS/PE).

Muitas das críticas às políticas de cotas, verbalizadas por representantes de diferentes partidos, revelavam a dificuldade de se encontrar mulheres candidatas. Dificuldade que trazia como solução às chamadas "laranjas" - termo utilizado para designar candidaturas de "mentirinha", inscrições que tinham como objetivo, apenas completar o quadro de candidaturas. Chama a atenção que este questionamento só se dê agora, com a entrada das mulheres na disputa política, pois este artifício sempre foi usado pelos partidos políticos que procuravam apresentar o máximo de candidaturas possíveis, para reforçar o voto na legenda. Ainda no plano do questionamento, algumas se perguntam porque a política de cotas não foi mais ousada, se as mulheres não deviam ter lutado por $50 \%$, ao invés de $30 \%$ das vagas?

"Quanto à política de cotas, porque não fomos mais arrojadas $\boldsymbol{e}$ propusemos $\mathbf{5 0 \%}$ ? Quando propusemos $30 \%$, foi uma questão de estratégia inicial, sei disso, mas foi uma estratégia tímida, mostrando que a mulher se considera muito aquém da realidade da sustentação no poder". (Ana Maria, candidata à Deputada Federal pelo PFL/TO).

A necessidade de um equilíbrio entre homens e mulheres nos espaços de representação política; o crescimento do número de mulheres interessadas em ocupar estes cargos; e um investimento "verdadeiro" dos partidos no sentido de incluir as mulheres, foram temas recorrentes no debate.

"É preciso que as mulheres de lideranças sejam estimuladas - e estamos tratando disso no movimento - a se candidatar, a ousar ir para esse lugar. Muito se falou sobre como ele é violento, como é castrador, como é difícil conciliar a vida privada com a pública. Mas há algo de dialético nos partidos. Precisamos discutir mais essa questão. Por que razão os partidos não conseguem se divorciar de práticas patriarcais, antigas e agressivas contra as mulheres e como as mulheres podem reforçar-se mutuamente a ponto de não esvaziar esse potencial e participar dos meios legislativos". (Ângela Freitas - AMB)

E a política de cotas também é vista como uma forma de divisão de responsabilidades entre os sexos, e a necessidade das próprias mulheres se apresentarem para estes lugares, foi reivindicada.

"Queremos paridade na representação política, não queremos mulheres nem homens em excesso ou insuficiência, mas em oportunidades iguais. Se homens e mulheres dividem o ônus e a responsabilidade da construção do nosso País, é preciso também dividir o ônus e a responsabilidade de decidir sobre os destinos". (Deputada Federal lara Bernardes - PT/SP)

Os partidos são, portanto, na visão da grande maioria das presentes, responsáveis por parte significativa das dificuldades que as mulheres enfrentam quando decidem se candidatar. Mas, os debates trouxeram à tona outras dificuldades para o bom exercício da vida pública, problemas que giraram em torno da articulação entre carreira política e vida familiar. 
TRANSFORMANDO A DIFERENÇA: AS MULHERES NA POLÍTICA

\section{Carrelra política e vida famillar}

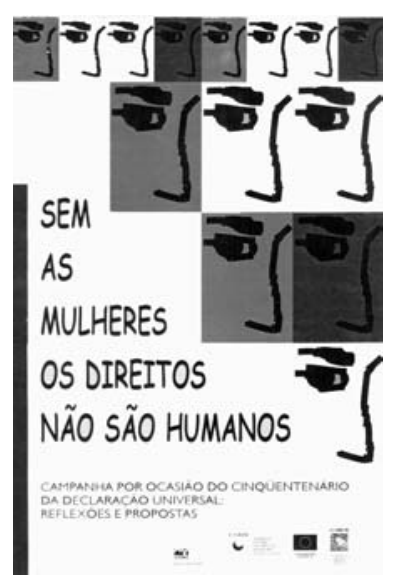

As tensões existentes na tentativa de conciliar a carreira política e a vida familiar, indicam que a "dicotomia entre público e privado", temática tão cara ao discurso feminista, que tem servido como um instrumento importante de análise, é um ponto central com o qual as mulheres se defrontam no cotidiano, mostrando que estes espaços estão em permanente relação.

Um dos pontos levantados, quando se pensa no exercício da política representativa, é a falta de referenciais sociais para as mulheres eleitas. Estas ainda são tratadas pelo masculino, nos remetendo para a recente entrada das mulheres neste campo. Um exemplo disso foi a inexistência de diplomas e carteiras com os cargos eletivos no feminino, demonstrando que a falta de apenas uma letra, o " $a$ ", pode significar muito no reconhecimento destas novas mulheres. Os depoimentos abaixo ilustram bem o quanto, até recentemente, estes espaços eram exclusivamente masculinos:

"Quando recebi esta carteira, estava escrito: Poder Legislativo. Vereador Eni Fernandes. Primeiro, por questão de respeito à mulher e, segundo, por que meu nome pode ser confundido, não aceitei a carteira. Fiz requerimento pedindo ao Presidente da Câmara que imprimisse nova carteira. Assim foi feito: Eni Fernandes, Vereadora". No documento de minha diplomação, estava escrito: 'Vereador: Eni Fernandes'. Fiz requerimento ao Tribunal Regional Eleitoral do Estado de São Paulo solicitando mudança. O Tribunal respondeu que não havia impressos destinados a mulheres, mas que, a partir de próxima eleição, a de 1998, haveria distinção". Foi um grande avanço. Precisamos estar atentas a estas questões, que às vezes podem parecer pequenas". (Vereadora Eni Fernandes - PT/São José do Rio Preto/SP)

"Inclusive quero lembrar, e será ação afirmativa importante para as mulheres, a inclusão da letra "a" nas cédulas eleitorais. Lembro-me de quando fui com Marta Suplicy e outras deputadas ao Tribunal Superior Eleitoral pedir isso. As candidatas deixaram de ser Vereador, Deputado, Senador, Governador e passaram a ter gênero reconhecido: Vereadora, Prefeita, Governadora, Senadora, Deputada. Por incrível que pareça, não fizeram esta adaptação. Fomos lá, pedir, exigir que fizessem. Então, é quase tudo assim: só na base do fórceps se consegue alguma coisa". (Deputada Federal Maria Elvira - PMDB/MG)

Esses problemas não são específicos do legislativo, como bem lembrou a presidente do Conselho Nacional dos Direitos da Mulher, se referindo ao Judiciário: ${ }^{25}$

"No âmbito estadual há pouquíssimas desembargadoras. Aliás, neste caso, há um fato hilário, em muitos dos tribunais não haviam banheiros femininos, porque

${ }^{25}$ Neste mesmo sentido, somente em 1997, o Senado Federal permitiu o uso de calças pelas mulheres. No Supremo Tribunal Federal, essa autorização só foi conseguida, em maio de 2000. 
MIRIAM PILLAR GROSSI E SÔNIA MALHEIROS MIGUEL

não previam que mulheres chegassem àquele cargo". (Solange Bentes - Presidenta do Conselho Nacional dos Direitos da Mulher)

Os depoimentos do seminário, também apontam que as dificuldades sentidas pelas mulheres para desenvolver uma carreira política são muito semelhantes às dificuldades sentidas em outras carreiras profissionais. A queixa, cotidianamente verbalizada, de que as mulheres para ocupar cargos de direção têm de sempre "fazer mais", para provar a sua competência, tão conhecida nas mais variadas profissões, esteve presente também no falas das mulheres que optaram por seguir a carreira política.

"Quero citar uma frase que li outro dia e achei extremamente interessante e me marcou muito. Parece-me ser da Margareth Tatcher, se não estiver equivocada: "Espera-se que as mulheres façam o dobro dos homens, na metade do tempo e sem mérito algum. Ainda bem que isso não é tão difícil". Acho que isso marca muito o nosso trabalho. (Deputada Estadual Célia Leão - PSDB/SP)

Além das competências profissionais e intelectuais, exigidas também para os homens, foram lembradas, outras exigências, particulares às mulheres, ligadas à aparência e ao bom cumprimento do seu papel tradicional de mãe e esposa:

"Hoje, as mulheres sabem que, para serem notadas, precisam não só de competência intelectual e profissional, mas ainda que sejam mais arrumadas e mais bonitas que o homem. As mulheres precisam estar sempre bem vestidas, têm de ser boas mães e boas esposas, enfim, cumprirem coisas que contam para ser consideradas dignas". (Prefeita Wilma Farias - PSB/Natal/RN)

A essas exigências, são acrescidas as raciais, como ser também branca, exigência assinalada por uma das participantes:

"Quanto à violência psicológica que sofremos, desde que o nosso corpo tem de se adaptar a padrões que não são os nossos, quer dizer, os conceitos de beleza internacional, acabamos por negar a nossa raça, nossa identidade e começarmos a trabalhar de forma contrária". (Marta - Conselho Municipal dos Direitos da Mulher de Sorocaba e Secretaria Estadual de Mulheres do PT)

Ouvindo os relatos das participantes tivemos a impressão de que as mulheres estão fadadas a sentirem-se sempre em falta frente ao mundo da política, pois raramente conseguem se ver no modelo ideal que é esperado delas, modelo que parece se centrar em dois atributos: a beleza e a maternidade.

\section{Filhos, maridos, casas}

A temática da maternidade foi uma das que mais mobilizou a fala das participantes. Em vários dos depoimentos as mulheres afirmavam quantos filhos tinham. As que não tinham filhos falavam da cobrança que recebiam constantemente, tanto por parte dos homens, quanto das próprias mulheres, para adequar-se à visão culturalmente difundida da inexorabilidade da maternidade e de que a identidade feminina se constitui com base nesta. 
TRANSFORMANDO A DIFERENÇA: AS MULHERES NA POLÍTICA

"Muitas vezes na minha vida política precisei confirmar que era uma pessoa normal (...), porque não tenho filhos, optei por não tê-los (...). Quando me perguntam - isto eu passei a notar com o tempo - quantos filhos tenho e eu falo que não tenho nenhum, fazem o malor silênclo. Já ouvi dizerem - 'coitada'. Ou eu tenho um defeito e as pessoas as vezes têm pena de mim ou ficam me olhando estranho (...). Então, a mulher tem que viver provando se é ou não é normal nessa questão." (Deputada Federal lara Bernardi - PT/SP)

Em muitos depoimentos, a maternidade é reconhecida como um poder, e este sim, seria o poder das mulheres. Seria no espaço da casa e da família que as mulheres teriam e exerceriam o poder.

"Acho que sempre tivemos poder, a partir da casa, do útero. Quem já pariu? Eu já pari dois filhos. (...) Temos poder sobre os filhos e o marido. (Fátima Movimento Negro de Belém do Pará e Grupo de Mulheres Negras)

"Temos intrinsecamente uma história de poder dentro de casa, dentro da família, até mesmo dentro do matriarcado, até porque somos fundamentais para as famílias. Sem nós, mulheres, nada acontece. Nem com os nossos homens vamos falar a verdade". (Deputada Federal Maria Elvira - PMDB/MG)

"Um eu perdi no ventre, seis eu tenho do ventre e três do coração - eu os criei. São dez ao todo. E isto, realmente, é motivo de poder". (Isabel Mendes Presidenta do Conselho Municipal da Condição Feminina de Curitiba e representante no Conselho Estadual do Paraná)

"Em última instância, somos nós quem geramos a vida, somos nós portadoras de características diferenciadas tão bem vindas, que queremos fazer com que estas características e diferenças sejam respeitadas, valorizadas, discutidas". (Deputada Estadual Lúcia Carvalho - PT/DF)

Mas, se a maternidade parece ser vista pela grande maioria das presentes como espaço fundamental do poder das mulheres, quando se tratou de refletir sobre outros significados do poder, observamos que o poder é visto como um lugar solitário, solidão reclamada por muitas mulheres. Por que o poder é tão solitário para as mulheres? Para muitas delas, no exercício da política é necessário, sobretudo, compartilhar o peso emocional do exercício do poder. Os homens quando estão num cargo de poder têm a primeira-dama, uma companheira obrigatória para as atividades da política. Inclusive, se o homem político não tiver a mulher ele corre riscos na sua imagem. E essa companheira, necessariamente, num modelo tradicional, ajuda o marido a fazer política. E, não só faz coisas concretas, mas sobretudo alivia-lhe a tensão e o sofrimento que o lugar do poder carrega.

E é isso que parece faltar às mulheres que estão no poder, pois muitas delas falaram sobre a ausência do companheiro, deste homem que elas gostariam que fosse um ombro amigo e solidário com a dor e a solidão do poder. Os homens, que estão ao lado das mulheres políticas, não foram treinados para suportar esse peso. As mulheres então continuam suportando o peso dos outros, dos homens, dos filhos etc., e o seu próprio peso, o que resulta, muitas vezes em separação conjugal. Vários depoimentos de mulheres políticas mostram que os 
MIRIAM PILLAR GROSSI E SÔNIA MALHEIROS MIGUEL

maridos acabam se separando uma vez que elas são eleitas, porque os homens não suportam estar em segundo plano. A separação dos maridos e companheiros, como conseqüência da inserção na vida polííica, é um dos problemas subjetivos que parece fundamental para as mulheres se elegerem, questão que antecede a temática das cotas.

"Tive a coragem de desmanchar um casamento há algum tempo e outro mais recentemente (Risos). Não me importei com as conseqüências por entender que meus direitos são iguais aos dos homens (...) A mulher na política tem que ter muito idealismo (...) deve saber que vai deixar filhos e família, vai perder o marido, terá que arranjar outro, que, provavelmente, perderá também. Essa é verdade". (Prefeita Wilma de Farias - PSB/Natal/RN)

É comum a queixa do descasamento, motivado pela vida política, mas em nenhum momento as falas se referiram às conquistas afetivas conseguidas também graças ao mundo da política, o que nos pareceu significativo da forma como as mulheres políticas lidam com imagens sociais de moralidade feminina. ${ }^{26}$

O reconhecimento de um "outro lugar" da mulher nas relações de conjugalidade foi lembrado por algumas das falas à partir de uma série de anedotas que remetem à inversão da relação tradicional de subordinação das muIheres aos homens, sugerindo que há poderes das mulheres. Como a brincadeira lembrada no intervalo do seminário: "Lá em casa, é sempre o homem quem tem a última palavra: Sim, querida".

"Há um ditado que diz que atrás de um grande homem há uma mulher, sempre houve mesmo, sempre houve alguém empurrando (Risos), ajudando, apoiando, cuidando da comida, da roupa, do psiquismo dele, dos filhos, da estrutura familiar, para ele ter tranqüilidade e ser astronauta, juiz, jogador de futebol, rei, imperador, etc. Sempre estivemos ali. Então, precisamos entender que isso foi muito nobre, foi muito bonito, mas estamos numa outra fase". (Deputada Federal Maria Elvira - PMDB/MG)

Muitas vezes, elas são alvo de questionamentos e boatos de que seriam "manipuladas" por outros (maridos, amantes, pai) como foi o caso da primeira prefeita eleita em 1982 pelo PT em Fortaleza, que era apelidada de "Dona Flor e seus dois maridos".

E, não raras vezes, os maridos se sentem numa posição de espera, tendo de organizar suas vidas em função do tempo das mulheres. Posição que é facilmente associada com "passividade" ou seja, com um atributo desvalorizado do feminino:

\footnotetext{
${ }^{26}$ Enquanto finalizávamos este artigo, um dos casais ideais da política brasileira, Marta e Eduardo Suplicy, ambos do PT, separou-se, tornando-se um tema de intenso debate nas mais diferentes rodas sociais e na imprensa. Entre as inúmeras explicações levantadas para a separação, salientamos duas: uma de que ele, senador da república, não estava suportando a visibilidade política da mulher, remetendo a um dos tipos de queixas das mulheres políticas presentes, de que os maridos "não suportam" a visibilidade delas; e outra, a de que ela teria um amante, remetendo à velha acusação de "pouca vergonha", e reafirmando à necessidade de um modelo moral superior da mulher política. Mas isto já assunto para outro artigo.
} 
TRANSFORMANDO A DIFERENÇA: AS MULHERES NA POLÍTICA

"As mulheres casadas sabem como é difícil a política. É muito mais fácil ser solteira, não ter marido. Os maridos exigem. Meu marido quando eu chegava em casa dizia assim: 'Eu sou a fêmea, você é o macho. Estou aqui como a fêmea te esperando. São 10 horas da noite, e você não chega'. É assim. Eles não aceitam". (Prefeita Wilma de Farias - PSB/Natal/RN)

Para impedir que o companheiro se sinta "passivo", na espera da mulher política, foi dado um depoimento muito interessante sobre a forma de integrar o homem em seu projeto político, o de torná-lo o assessor que deve fazer a agenda, tópico que parece ser central nas discórdias conjugais.

"(...) meu primeiro casamento já acabou, porque meu ex-marido me fazia concorrência muito grande. Já estou partindo para o segundo casamento. Para resolver o problema, Prefeita, coloquei o meu futuro marido como meu assessor. Ele faz a minha agenda, obriga-me a cumpri-la e acompanha-me, e não há mais problema. Acho que esse passo deu certo. Percebi que cresci mais nestes últimos seis meses em que ele está trabalhando comigo do que quando permitia brigas. Ele perguntava: 'aonde você vai? A que horas vai chegar em casa?' Estou conseguindo conciliar a vida familiar e a vida pública". (Vereadora Darcy Vera, de Ribeirão Preto/SP).

Alguns depoimentos referem-se à responsabilidade das mulheres na situação de desigualdade nas relações de gênero, sobretudo no que diz respeito à divisão das tarefas domésticas e à responsabilidade com o cuidado dos filhos:

"E quem deixa no primeiro ou segundo dia de vida do neném o marido dar banho? Acha que o menino vai cair. Absolutamente! Eu pelo menos deixei porque é um ser humano que tem olho, boca, perna e braço e sabe segurar uma criança como nós. Mas pelo poder exercido não se deixa". (Fátima - Movimento Negro de Belém do Pará e Grupo de Mulheres Negras)

A relação com o espaço doméstico: cozinhar, lavar, passar, limpar foi uma temática bem menos abordada do que a relação com filhos e maridos. Falou-se no seminário sobre a importância que o companheiro compartilhe as tarefas domésticas. Esse seria um ponto de partida para a busca de igualdade na relação conjugal. No entanto, alguns depoimentos nos apontam para a ambigüidade da relação da mulher profissional da política com o espaço do lar. Para algumas as tarefas da casa são prazerosas, feitas pessoalmente e para as quais se busca conquistar o marido:

"Tenho o maior prazer de estar na minha casa, de cuidar de meus filhos, de fazer a tarefa com eles, de cozinhar. Não temos de inverter nossos paradigmas, mas fazer com que os companheiros também participem dessa coisa boa. (...) Temos de conquistá-los para essas tarefas que nós já realizamos, para que possamos também conquistar as tarefas que o mundo oferece aos nossos companheiros". (Deputada Estadual Lúcia Carvalho - PT/DF)

Para outras, é a empregada quem ocupa esse lugar. Solução questionada por militantes negras presentes na platéia, que trouxeram à tona uma velha te- 
MIRIAM PILLAR GROSSI E SÔNIA MALHEIROS MIGUEL

mática abordada pelo movimento feminista no Brasil, a da relação de exploração entre as próprias mulheres:

"O slogan que estamos usando hoje é o seguinte: - 'atrás de uma grande mulher há sempre uma grande empregada'. Estamos passando a exercer o poder de escravizar outras mulheres". (Marta, Conselho Municipal dos Direitos da Mulher de Sorocaba e da Secretaria das Mulheres do PT)

Por fim, é interessante observar que muitas citaram a rede de apoio feminina para cumprir o mandato político: são mães, irmãs, cunhadas, comadres, amigas que apoiam as mulheres. Há, de alguma forma, neste apoio a certeza de que quem representa está fazendo um trabalho coletivo, trabalho que remete de forma muito freqüente à discussão sobre o significado do poder para as mulheres.

\section{Poder e Sensibilidade}

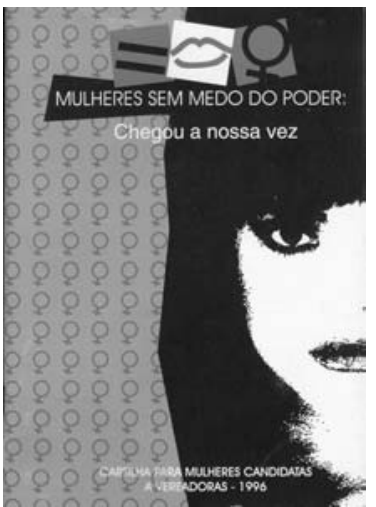

Uma das questões que mobilizou bastante o plenário foi a temática do poder. Percebemos que há diferentes percepções do que significa o poder. Para algumas falas, o poder têm gênero. Ou seja, o poder é masculino e é exercido num lugar determinado, o espaço público da política, e nesta mesma linha explicativa, as mulheres teriam poderes ligados a outros espaços, como a família e o lar. Num outro polo explicativo, o poder seria neutro, podendo ser exercido tanto por homens quanto por mulheres. Outra temática subjacente ao exercício do poder, foi a competição pelo poder, ora vista como uma postura masculina. Ora como uma postura constituidora do exercício da política.

"Quero dizer com isto que essa participação ou exercício não significa a ocupação de uma função masculina por nós, mulheres, mas representa o reconhecimento de um direito igualitário, a ser compartilhado entre o homem e a mulher, de exercer em comum responsabilidades públicas e participar do governo e da sociedade de que ambos são parcelas em total igualdade". (Senadora Telma Siqueira Campos -PPB/TO).

O depoimento abaixo fala, mais uma vez, dos poderes diferentes de homens e mulheres, apontando para o poder existente, em ambos os lados, ainda que em uma relação de dominação e submissão entre homens e mulheres:

"Durante muito tempo, o homem viu um lado do poder, e a mulher viu o outro. O homem viu o poder de mandar $\theta$ a mulher 0 de se submeter. A mulher fazia a política de conquista para o homem exercer o poder de mando. Temos visão diferente da mesma relação". (Marta de Oliveira - Conselho Municipal dos Direitos da Mulher de Sorocaba/SP e Secretaria de Mulheres do PT; candidata a vereadora, em 1996) 


\section{TRANSFORMANDO A DIFERENÇA: AS MULHERES NA POLÍTICA}

A competição entre os sexos é uma questão que aparece como piada sobre o poder "invisível" das mulheres, como no exemplo bastante conhecido, de Hillary e Bill Clinton:

"A piada é sobre Bill e Hillary Clinton. Eles foram a um evento e, ao saírem, passaram num posto de gasolina. E lá Hillary Clinton começou a conversar com um senhor da idade dela, com muita intimidade, com muita alegria. Então, Bill Clinton logo perguntou: 'Mas quem é esse com quem você está conversando tão intimamente?' Ela respondeu: 'Ah! Esse é um grande amigo meu. Imagine que ele foi meu namorado, quando solteira, antes de conhecer você'. Ele retrucou: 'Ah! Pois é, se você não tivesse se casado comigo, casaria com o dono do posto de gasolina'. Ela disse: 'Não, se tivesse me casado com ele, ele seria o presidente dos Estados Unidos" (Risos). (Deputada Federal Maria Elvira - PMDB/MG)

Na reflexão que vê o poder como algo neutro, lugar que poderia ser ocupado por homens ou mulheres, aparece como justificativa importante da resistência das mulheres a se candidatarem, uma educação sexista que as impede de "gostar do poder". Para esta corrente as mulheres precisam fazer um trabalho sobre si, para superar seus próprios preconceitos e limitações.

"Não basta disputarmos e conquistarmos o poder. Primeiro é preciso que gostemos dele. Fomos educadas, formadas e induzidas ideologicamente a não gostar do poder e a achar que é coisa para homem. Até utilizamos um mecanismo psicológico para justificar este fastio, esta falta de apetite pelo poder, dizendo que é coisa pouco nobre, de homem, que cede à corrupção e á imoralidade, fazendo concessões éticas. Dispensamo-nos, assim, do esforço de disputa-lo e conquistá-lo". (Deputada Federal Luiza Erundina - PSB/SP)

No mesmo sentido, também se falou do poder enquanto verbo, remetendo ao provérbio "querer é poder". Nesta fala o "poder" deixa de ser visto como um objeto/lugar a ser conquistado pelas mulheres, e passa a ser uma ação que deve ser empreendida consigo mesma:

"Quero dar apenas uma sugestão. Todo mundo tem em sua geladeira aqueles enfeites com imã, que estão na moda. A geladeira é o lugar que mais atacamos. (...). Então, na porta da geladeira, que abrimos a qualquer hora do dia ou da noite, coloquem um papel (...) onde esteja escrito em letras grandes: 'Eu posso'. E poder, todo mundo pode, basta querer". (Deputada Estadual Célia Leão - PSDB/SP)

Os depoimentos sobre o acesso ao poder por parte das mulheres circulam entre uma perspectiva mais psicológica e outra mais psicanalítica. De um lado, uma visão centrada na "auto-estima". E de outro, uma visão que remete à categoria de "desejo":

"Eu queria dizer o seguinte: nós temos casas-abrigo e casas-albergue para mulheres em situação de risco. No entanto, para conseguir verbas e apoio financeiro, é muito complicado. E, num segundo tempo, quando nós resgatamos a auto-estima, existe o problema de recolocá-las no trabalho. Ou seja, essas mulheres estão desqualificadas. Existe uma proposta, que está começando a ser implementada em 
MIRIAM PILLAR GROSSI E SÔNIA MALHEIROS MIGUEL

âmbito nacional, que é a do cooperativismo. (...) Então, que tipo de apoio as mulheres que se juntam em cooperativas, de famílias carentes, com problemas e mesmo em situação de risco podem conseguir em termos de financiamento, de apoio, de bancos de dados, de estrutura para se montar uma cooperativa?" (Marta - Conselho Municipal dos Direitos da Mulher, de Sorocaba).

"Gostei muito do que disse a deputada Luiza Erundina nesta Casa, quando citou o desejo do poder. A mulher tem vergonha de verbalizar este desejo. É um desejo, sim, muito correto, muito importante para conquistarmos". (Ika Fleury - Presidente Nacional do PTB Mulher).

"É todo um trabalho de persuasão, é preciso lhes dizer que isto é importante, que elas viverão uma experiência rica nas suas vidas, que contribuirão para a democracia, que irão contribuir com todas as mulheres e com os homens também". (Deputada Federal Maria Elvira - PMDB/MG).

Algumas não se esquecem de lembrar que poder é mandar, é decidir, é assumir a responsabilidade pelo coletivo. Exercer o poder nem sempre é fácil para as mulheres eleitas, como lembra a prefeita de Natal:

"Eles não aceitam que você mande ou decida. Acontece que eu tenho que mandar. Eu sou a prefeita. Quem vai mandar sou eu. Quem vai decidir sou eu. (Risos) (Palmas)". (Prefeita Wilma Farias - PSB/Natal/RN)

Outras têm claro que poder e política não são exatamente a mesma coisa, e que muitas mulheres exercendo cargos políticos ainda estão excluídas do poder:

"Não estamos no poder, mas estamos na política" (Palmas). (Vereadora Eni Fernandes - PT/São José de Rio Preto/SP).

No mesmo sentido, também se lembrou que política é algo diferente de poder, e que deve ser vivida no cotidiano, como exercício de cidadania.

"Não é fundamental que ela entre em um partido político, mas a mulher tem de entender a cada passo que o preço do arroz, do feijão, da escola do seu filho e do uniforme, passa pela política". (Deputada Estadual Célia Leão - PSDB/SP)

Certas falas sugerem, como uma das formas de alterar a situação das mulheres, o uso de qualidades já reconhecidas como femininas, como, por exemplo, o seu poder de sedução:

"Quando queremos seduzir, somos perigosas. Acho que quando eleitas temos de ser perigosas para seduzir exatamente o sistema e mudar para a política de gênero". (Palmas). (Fátima - Movimento Negro de Belém do Pará e Grupo de Mulheres Negras)

O poder é portanto lugar de múltiplos significados, que vão do exercício da política à sedução, que parece ser uma das grandes armas femininas. Mas o poder feminino parece estar inexoravelmente associado à sensibilidade que seria inerente às mulheres, seja por "natureza", seja por "educação".

\section{Sensibilidade}




\section{TRANSFORMANDO A DIFERENÇA: AS MULHERES NA POLÍTICA}

Na articulação entre desejo do poder e formas culturalmente construídas como o do gênero feminino, há uma recorrência ao exemplo da maternidade, como "naturalmente" intrínseco às mulheres e lócus de poder feminino. Seria pela experiência e exercício da maternidade que muitas mulheres se habilitariam para o "social".

"Quem viver verá. Tenho certeza de que nós, mulheres, vamos chegar ao poder (Palmas). E vamos inclusive demonstrar (...) que queremos exercer o poder, que não temos medo do poder, até se considerando as qualidades inerentes à muIher, que vêm com a maternidade, de sua preocupação com o outro, de seu sentimento social". (Deputada Federal Maria Elvira - PMDB/MG).

"(...) Quem sabe se não é papel da mulher, ocupando cargos de poder (...) por sua sensibilidade dada pela maternidade, pela sensibilidade social dada pela luta secular contra a exclusão". (Deputado Federal Fernando Coruja - PDT/SC).

É inegável que muitas parlamentares têm uma dedicação especial a projetos na chamada "área social". Na cultura política brasileira, que evidentemente faz parte de uma políitica mais geral, ocidental, a ênfase está no econômico, em detrimento do social. E este continua sendo um ponto nevrálgico do exercício da política feita por mulheres, uma vez que a grande maioria das eleitas tem uma sólida competência em áreas como saúde, educação, assistência social, áreas até agora desvalorizadas no Brasil. Um argumento que começa a se fazer ouvir, é que não existe econômico que não seja social:

"(...) existe até certo preconceito contra nossos projetos: 'Vocês só fazem projetos na área social?' Fazemos projetos também na área econômica. Mas para nós, a visão do econômico está diretamente ligada ao social. Não nos interessa o econômico senão atendermos ao social (Palmas)". (Deputada Federal Maria Elvira - PMDB/MG)

Em muitos depoimentos, há o reconhecimento de que haveria uma política diferente feita pelo gênero feminino, uma política marcada por uma ética particular as mulheres.

"Hoje, duas questões se levantam com grande intensidade e preocupação: Uma é a questão social e a outra é a ética na política. Ninguém melhor que a mulher se movimenta neste espaço. Naturalmente, pelo exercício desta exclusão, ela tem grande sensibilidade em relação a questão social". (Eliane Calmon Ministra do Supremo Tribunal de Justiça).

A mulher na política é seguidamente associada nos discursos políticos como detentora de um conjunto de qualidades que se expressam na categoria "sensibilidade".

"(...) a conquista de um novo espaço e de um novo papel para que possamos demonstrar a nossa competência, capacidade e, essencialmente, a nossa sensibilidade. Por causa de todos os aspectos culturais e subjetivos da realidade, transformamo-nos em pessoas bastante sensívels". (Deputada Federal Jandira Feghali - PC do B/RJ)

"Temos de transformar a cultura política e o exercício do poder fazendo-o de forma feminina, ética, sensível, solidária e democrática. Dessa forma, poderemos contribuir e dar um novo tom a este processo e à cultura política em nosso país".(Deputada Federal Luiza Erundina - PSB/SP) 
MIRIAM PILLAR GROSSI E SÔNIA MALHEIROS MIGUEL

A sensibilidade feminina é vista como contraponto a um padrão masculino de governar:

"Não podemos reproduzir a forma autoritária, centralizadora, dominadora e patriarcal de exercer o poder, o padrão masculino vigente em sociedades como as nossas". (Deputada Federal Luiza Erundina - PSB/SP)

Estes atributos - ética, solidariedade, justiça, fraternidade, democracia - justificariam a participação das mulheres na política, como se as mulheres fossem necessárias por sua "diferença", por qualidades inatas ao sexo feminino. Características que os homens e a sociedade em geral teriam que receber "via educação".

"Acredito que nunca foi tão necessária a presença da mulher na política, não só por questão de direito e igualdade, mas de sensibilidade". (Deputado Federal José Dirceu - PT/SP)

"Como ser humano, o homem também é sensível, meigo e tudo. Ele tem que exercitar isto mais do que nós". (Fátima Mattos - Presidente do Conselho Municipal da Condição Feminina, Belém/PA)

"Enfim, precisamos mudar o atual modelo, que não serve para a maioria da população, não serve para nós, que somos maioria da população, e principalmente para a maioria que quer espelhar-se em nós, políticos, para que a sociedade seja mais ética, mais justa, mais fraterna, enfim, para ter sensibilidade". (Palmas) (Vereadora Eni Fernandes - PT/São José do Rio Preto/SP)

Alguns dos homens parlamentares presentes buscaram uma proximidade com as mulheres participantes do seminário, expressando sentimentos. E os argumentos de muitos deles, para justificar a incorporação das mulheres na política, se baseavam na necessidade de fazer com que estes atributos das mulheres, fossem também atribuídos à política e aos próprios homens:

"Quero dizer da minha satisfação de estar presente neste encontro e trazer meu afeto e meu carinho a todas essas mulheres, porque triste de mim se não fossem as mulheres!". (Deputado Federal Severino Cavalcante - PPB/PE - Segundo vice-presidente da Mesa da Câmara dos Deputados)

Por isso, neste momento, representando o PDT e a Deputada Miriam Reid, desejo que este encontro tenha o melhor final, que se consiga tirar daqui as melhores proposições, e deixo minha crença de que o processo é inexorável, queiram ou não aqueles que acham que isso não deva acontecer, a mulher já conquistou o seu papel na sua luta pela igualdade. Hoje em São Paulo duas mulheres disputam, palmo a palmo, a prefeitura do maior Município deste País, do qual, inclusive, a Deputada Luiza Erundina já foi Prefeita. Por isso, neste caminhar, a revolução feminina, a "revolução dos estrogênios", vai fazer com que a igualdade em termos sociais aconteça. (Fernando Coruja - PDT/SC)

Sensibilidade, afeto, carinho, parecem ir de par com as mulheres na maior parte dos discursos do seminário. Estas questões, não por acaso, parecem ser recorrentes no senso comum sobre o verdadeiro papel das mulheres na política, o de tornar os espaços do poder menos "áridos", menos cruéis e mais dignos. ${ }^{27}$

\footnotetext{
${ }^{27}$ Neste sentido, também é ilustrativo o embate na segunda metade do mês de abril de 2001 entre dois homens
} 


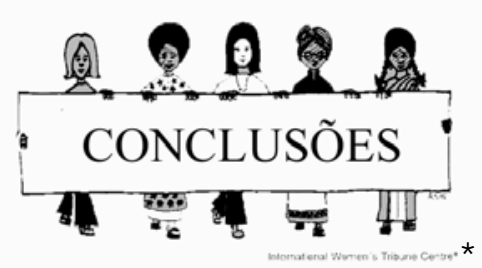

Três foram os grandes eixos temáticos que permearam o seminário "Mulheres na política - Mulheres no poder": a questão das cotas e das políticas afirmativas, a articulação entre carreira política e família e a forma que o poder toma quando exercido pelas mulheres, representada na palavra "sensibilidade".

\section{As cotas e outras ações afirmativas}

Constatamos, nas diferentes intervenções no seminário, que o tema da participação política das mulheres não é um assunto "novo" nem para as militantes, nem para as pesquisadoras feministas, mas que a "política das cotas" é percebida como uma nova forma de se encarar esta questão, marcada até o presente por dois grandes temas: a participação das mulheres na política tradicional, por alguns chamada de "política dura" e a presença delas em movimentos sociais, vistos como espaços "alternativos" do fazer política.

A políitica das cotas se insere no conjunto daquilo que se denomina de ações afirmativas, por sua possibilidade de impacto efetivo nos resultados eleitorais, e também no sentido da tão falada e desejada transformação cultural.

Apesar de haver um entusiasmo coletivo e uma defesa incondicional, por muitas das presentes, da manutenção das políticas de cotas, foi lembrado também que não houve um aumento significativo de mulheres eleitas, o que indicaria que a lógica política eleitoral é que definiria a escolha das candidaturas e não a lógica do sexo/gênero, expressa na lei das cotas.

Por lógica eleitoral foram arrolados diferentes elementos. Falou-se tanto da forma como se dão as eleições no Brasil, por candidaturas e não por listas eleitorais, quanto da política interna dos partidos que, via de regra, excluem as mulheres das principais disputas eleitorais. Alguns depoimentos dão exemplos flagrantes desta resistência dos partidos e nos desvendam mecanismos invisíveis deste tipo de exclusão. Não se pode negar, no entanto, que são nestes embates políticos que muitas mulheres fortalecem suas candidaturas e posições políticas.

senadores e uma funcionária graduada do Senado no caso da violação do painel de vołação. Na forma como a imprensa cobriu este drama social foi possível, mais uma vez, perceber como a fala da mulher é vista ora, como suspeita, ora como verdadeira, devido à sua sensibilidade e dignidade.

* Apud Articulação de Mulheres Brasileiras 
MIRIAM PILLAR GROSSI E SÔNIA MALHEIROS MIGUEL

Além da conquista da lei de cotas, foram destacadas outras ações afirmativas que buscam tirar as mulheres do plano da invisibilidade no campo das representações sociais. São pequenas ações, concretas e imediatas, que têm o objetivo de combater a discriminação das mulheres no acesso ao poder e reequilibrar as relações existentes. Entre os exemplos dados nos pareceram extremamente significativos, os trazidos pelas Deputadas Federais lara Bernardi e Maria Elvira, e pela Vereadora Eni Fernandes, que falam das sutis resistências ao feminino nestes espaços.

Ao lutar pela inclusão de "apenas um a" no diploma, na placa em frente à porta do gabinete, na cédula, na urna, no crachá ou na carteira profissional de identificação as mulheres entendem que estes atos modificam de forma significativa o olhar sobre a representação pública das mulheres eleitas, que exigem serem reconhecidas por sua identidade de gênero feminina.

É possível perceber, com este pequeno exemplo, o quanto no Brasil, a feminilização dos cargos e títulos tem um grande significado nas lutas feministas, diferentemente de outros lugares (e outras línguas), como na França, onde não há consenso sobre a necessidade de feminilizar a língua, uma vez que o prestígio das carreiras parece estar associado ao masculino.

\section{Vida pública $\mathrm{x}$ família}

Os depoimentos do seminário nos mostram que ainda é difícil para as muIheres optar pela política, como carreira, pois existem inúmeros empecilhos que se colocam no âmbito familiar, seja pela resistência dos maridos, seja pela forma de lidar com questões domésticas, como filhos e cuidados com a casa. Não há dúvida de que a presença de mulheres nas câmaras municipais, estaduais e federais, transforma as relações de gênero em diferentes instâncias, não apenas no mundo da política, mas também no campo das relações familiares e afetivas, como testemunharam várias das presentes.

É inegável, pelos depoimentos que ouvimos, que a carreira política é uma carreira profissional que exige investimentos e aprendizagens muito particulares. As falas das deputadas e vereadoras presentes são ilustrativas do longo aprendizado das regras que regem o mundo da política, necessário para se conquistar um cargo político, se referindo àquilo que muitos autores no Brasil denominam "cultura política". Esta nos parece uma das pistas de investigação a ser aprofundada: a política enquanto uma carreira profissional.

Muitos estudos têm apontado que a entrada das mulheres na disputa política se faz por dois grandes canais: a participação em movimentos sociais (grupos de bairro, sindicatos, etc.) e as relações familiares (o parentesco com um homem políico - em geral pai ou marido). E os depoimentos, mais uma vez, reafirmaram essas vias privilegiadas de acesso.

É comum se ver associado, às essas duas formas, juízos de valor. Para mui- 
TRANSFORMANDO A DIFERENÇA: AS MULHERES NA POLÍTICA

tas análises, chegar à políitca pelo primeiro canal, o da participação em movimentos sociais, seria "enobrecedor", mas chegar à política pelo segundo canal, o das relações de parentesco seria "desabonador", pois se estaria entrando na política "facilitada" por relações de clientelismo, presentes na cultura política brasileira. As mulheres que entram na carreira política pelo primeiro canal são valorizadas pelo seu "esforço pessoal" e por terem o coletivo, como mote. As mulheres que entram na carreira política pelo segundo canal são acusadas de terem sido eleitas "ilegitimamente", por se terem beneficiado tanto do prestígio, quanto das alianças feitas por ou em nome do pai ou do marido.

Mas esta parece estar se tornando uma restrição exclusiva para o espaço da política. Hoje em dia, o fato de uma mulher decidir seguir a mesma carreira de prestígio exercida pelos pais, como por exemplo, medicina, direito ou artes é visto socialmente como positivo e apoiado pelos familiares e amigos, com orgulho. No entanto, não parece que o mesmo aconteça com as mulheres criadas em famílias de tradição política, que resolvam seguir a mesma carreira (geralmente do pai, pois ainda são poucas as mães políticas). Isso não é percebido, em muitas das análises, como algo positivo, como nos outros exemplos.

Ora, a carreira política, diferentemente de outras carreiras profissionais, é mais fortemente representada como uma carreira com duplo sentido, ora como fruto de projeto coletivo ideológico, ora como fruto de um projeto totalmente individual. Por detrás da crítica a essas mulheres parece haver um visão de que a política deva ser somente vocação, e não uma carreira que exigiria um longo processo de formação.

Felizmente algumas das falas no seminário se contrapõem a este tipo de discurso, bastante comum entre nós, feministas, e nos estudos sobre a participação política das mulheres; falas estas que valorizam, também, na caminhada das mulheres que seguiram tradições familiares no campo da políitica, a sua própria autoria e desejo, reconhecendo que muitas mulheres que contaram com o prestígio político dos seus maridos ou pais, tomaram rumos independentes $e$, muitas vezes, até superaram o prestígio dos seus familiares.

\section{O Poder e a Sensibilidade}

Para muitas das presentes no seminário, a política, tal como é praticada nas instâncias legislativas, teria características masculinas. Que características masculinas da política seriam essas? Judith Butler (1998), em reflexão sobre a constituição contemporânea do sujeito político, sugere a existência de um "sujeito ocidental masculinizado", ou seja, que tanto homens quanto mulheres atuando dentro dos parâmetros da política instituída, reproduziriam os mesmos atos codificados como políticos, que seriam portanto masculinos.

Esta não seria uma particularidade do legislativo brasileiro. No mundo sindical e de um partido de esquerda analisados por Sartori (1999) e Godinho (2000) 
MIRIAM PILLAR GROSSI E SÔNIA MALHEIROS MIGUEL

vale "quem fala mais alto", características associadas a um modelo "masculino" de fazer política (o oposto daquela "sensibilidade" tão decantada por homens e mulheres defensores da entrada das mulheres na política). Voltamos a uma questão nodal da reflexão teórica sobre gênero e política: se a política, por ser associada com o público, não é considerada, algo do masculino.

Um outro tema recorrente nas falas é o reconhecimento da sensibilidade como um atributo das mulheres. Mas o que chama a atenção é que neste momento a sensibilidade é colocada, no discurso de mulheres e de homens, como um valor positivo para ser incorporado ao campo da políitica. Se antes o perfil de um políico era a firmeza, a autoridade (e todos aqueles outros atributos atribuídos em nossa sociedade, ao masculino), hoje neste perfil, que inclui agora também a presença das mulheres, a "sensibilidade", a "ética" da preocupação pelos outros, começam a ser vistas como posturas necessárias, no exercício do poder. Esta seria uma das "diferenças valorizadas", na participação da mulher na política.

Para muitas, uma das "vantagens" da entrada das mulheres no espaço da política seria a sua capacidade, senão de transformar a chamada "política dura" (hard), em "políitica leve" (soft), pelo menos de suavizá-la, a partir da sua tão decantada "sensibilidade".

Os números ainda não mudaram, mas a forma de fazer política está mudando. No momento, estamos em pleno embate sobre o que é a política feita pelas mulheres, porque parece haver unanimidade na afirmação que as mulheres são mais "sensíveis" ao social. Ou, antes disso, que existiria uma diferença entre a política feita pelos homens e a política feita por mulheres, sendo que, no cerne desta diferença, estaria a "sensibilidade". Dois argumentos são utilizados para explicar esta sensibilidade, um que aponta que ela seria "natural" pelo exercício da maternidade ${ }^{28}$ e outro que a veria como "construção social" das mulheres, a partir do cuidado com os outros, inseridas em profissões como as de professoras, enfermeiras, médicas ou assistentes sociais.

Os argumentos acima foram utilizados inúmeras vezes durante o seminário, nos fazendo pensar na reflexão feita por Joan Scott sobre a luta pela paridade na França ${ }^{29}$ e seus efeitos concretos no governo socialista francês de Lionel Jospin, que no período 1997/2001 teve mulheres nos ministérios escolhidos como os prioritários, entre eles os de Ação Social, Justiça, Meio Ambiente e Educação. ${ }^{30} \mathrm{O}$ exemplo francês, além de ser emblemático do compromisso do Partido Socialista com a implantação da lei da paridade no executivo e legislativo, mostra como a presença das mulheres em cargos-chaves e valorizados estimula positivamente

\footnotetext{
${ }^{28}$ Este olhar, que de alguma forma coloca a mulher (e também o homem) ligados à "natureza", é bastante criticado por correntes do feminismo, que vêem nesta leitura uma posição retrógrada, que voltaria a essencializar as mulheres, colocando mais uma vez o destino de suas vidas nas mãos inexoráveis dessa tão decantada "natureza".

${ }^{29}$ Scott, Joan W. "La querelle des femmes" in the late twentieth century, New Left Review, 1997.

${ }^{30}$ Ministérios ocupados respectivamente por Martine Aubry, Elisabeth, Dominique Voynet e Ségolène Royal, responsável pela Educação Primária e Secundária no Ministério da Educação.
} 
TRANSFORMANDO A DIFERENÇA: AS MULHERES NA POLÍTICA

o imaginário a respeito das mulheres na políica, revertendo em muito pouco tempo, posições totalmente contrárias à leis de cotas. ${ }^{31}$

No Brasil, alguns partidos têm um discurso que privilegia o social, e nisto saúde e educação são as principais retóricas das plataformas eleitorais, mas quando assumem o executivo não conseguem colocar estes lugares no centro da política. Por que? Uma das explicações levantada no seminário é de que a competência maior para estes temas ainda é das mulheres políticas e que estas, quando chamadas a exercer secretarias e postos chaves em campos como saúde, cultura e educação são, via de regra, relegadas a uma posição desvalorizada no interior do próprio partido e/ou da coligação que está no poder.

Às vezes, os lugares considerados "femininos", mesmo quando ocupados por homens, são desvalorizados, como analisou Ari Sartori a respeito da estigmatização dos homens que ocupam os cargos de cultura e formação no mundo sindical. É inegável que há uma "cultura machista" muito presente em diferentes instâncias políticas, sejam elas de direita ou de esquerda. O fato de a grande maioria dos partidos políticos não terem adotado, ainda, uma política interna efetiva de inclusão das mulheres em cargos de direção, e de muitos deles se considerarem livres de tomar tal atitude, usando como justificativa a aprovação da lei de cotas para as eleições proporcionais, nos mostra que as mulheres e os homens têm ainda um campo imenso de desafios e de possibilidades, na construção de diferentes relações de igualdade.

O reconhecimento do feminismo, valorizado nos discursos do seminário, nos afigurou uma das grandes mudanças no mundo da política e dos movimentos de mulheres. Se, até o início dos anos 90, parecia de bom tom, para muitas mulheres candidatas, se declararem "femininas e não feministas", hoje esta dicotomia identitária pelo visto se desfez, pelo menos entre as mulheres políticas presentes no evento. Isto, para nós, constitui um dos grandes ganhos deste momento da luta feminista, refletindo uma efetiva e crescente penetração ${ }^{32}$ das idéias feministas na teia social.

\footnotetext{
${ }^{31}$ Nas últimas eleições municipais francesas, de março de 2001, a lei da paridade foi implantada pela primeira vez, com importantes resultados para as candidatas de todos os partidos. Lembre-se que a França era até então um dos países europeus com menor proporção de mulheres nos cargos legislativos.

${ }^{32}$ Segundo o dicionário Aurélio: Verbete: penetração 4. Fig. Capacidade de atingir o mais fundo do pensamento, dos sentimentos, das idéias de uma pessoa ou de um grupo:
} 
MIRIAM PILLAR GROSSI E SÔNIA MALHEIROS MIGUEL

\section{Referênclas Blbllográflcas}

BERNARDI, lara. Vereadora 2000: agora são outros 500! Subsídios para mulheres candidatas a vereadoras. Brasília: Câmara dos Deputados, 2000. 28 p.

BRASIL. Câmara dos Deputados. Notas taquigráficas do Seminário Mulheres na política, Mulheres no poder. Brasília, 16-18 maio 2000.

BUTLER, Judith. "Fundamentos contingentes: o feminismo e a questão do pós-Modernismo". Cadernos Pagu , n. 11, p. 11-42, 1998.

CONFERÊNCIA MUNDIAL SOBRE A MULHER, 4, 1995, Beijing. Relatório e Plataforma de Ação. Rio de Janeiro: FIOCRUZ, 1996. 352 p.

LEON, Magdalena. "Empoderamiento: relaciones de las mujeres con el poder". Revista Estudos Feministas, v. 8, n. 2, p. 191-205, 2000.

MIGUEL, Sônia Malheiros. A política de cotas por sexo: um estudo das primeiras experiências no legis/ativo brasileiro. Brasília: CFEMEA, 2000. $216 \mathrm{p}$

RODRIGUES, Almira. Mulheres: Movimentos sociais e partidos políticos. CFEMEA, Brasília. Disponível em: http://www.CFEMEA.org.br

SARTORI, Ari. Homens e as políticas de empoderamento das mulheres: A emergência do gênero entre sindicalistas de esquerda em Florianópolis (dissertação de mestrado). Florianópolis: UFSC, 1999.

SCOTT, Joan W. "La querelle des femmes" no final do século XX. Revista Estudos Feministas, volume 9, n. 2, 2001 (no prelo). Tradução de "La querelle des femmes in the late century, New Left Review 
TRANSFORMANDO A DIFERENÇA: AS MULHERES NA POLÍTICA

\section{Quadro 1 \\ Candidat@s por Unidade da Federação - 2000 Câmara de Vereadores}

\begin{tabular}{|c|c|c|c|c|c|c|c|c|}
\hline \multirow[t]{2}{*}{$\mathbf{U F}$} & \multirow{2}{*}{$\begin{array}{c}\text { Municípios } \\
2000\end{array}$} & \multicolumn{2}{|c|}{ Mulheres } & \multicolumn{2}{|l|}{ Homens } & \multicolumn{2}{|c|}{ Sexo nāo informado } & \multirow[t]{2}{*}{ Total } \\
\hline & & Quantidade & $\%$ & Quantidade & $\%$ & Quantidade & $\%$ & \\
\hline $\mathrm{AC}$ & 22 & 266 & 21,80 & 954 & 78,20 & 0 & 0,00 & 1.220 \\
\hline $\mathrm{AL}$ & 102 & 1.072 & 19,42 & 4.447 & 80,55 & 2 & 0,04 & 5.521 \\
\hline $\mathrm{AM}$ & 62 & 1.098 & 19,63 & 4.495 & 80,35 & 1 & 0,02 & 5.594 \\
\hline $\mathrm{AP}$ & 16 & 288 & 21,43 & 1.056 & 78,57 & 0 & 0,00 & 1.344 \\
\hline $\mathrm{BA}$ & 417 & 4.427 & 17,43 & 20.967 & 82,53 & 10 & 0,04 & 25.404 \\
\hline CE & 184 & 1.982 & 18,03 & 9.012 & 81,97 & 0 & 0,00 & 10.994 \\
\hline $\mathrm{ES}$ & 78 & 1.372 & 18,08 & 6.218 & 81,92 & 0 & 0,00 & 7.590 \\
\hline $\mathrm{GO}$ & 246 & 2.698 & 19,10 & 11.424 & 80,88 & 2 & 0,01 & 14.124 \\
\hline $\mathrm{MA}$ & 217 & 2.926 & 21,17 & 10.886 & 78,76 & 9 & 0,07 & 13.821 \\
\hline $\mathrm{MG}$ & 853 & 10.793 & 18,27 & 48.269 & 81,71 & 10 & 0,02 & 59.072 \\
\hline MS & 77 & 1.192 & 21,79 & 4.278 & 78,21 & 0 & 0,00 & 5.470 \\
\hline $\mathrm{MT}$ & 139 & 1.440 & 19,61 & 5.899 & 80,35 & 3 & 0,04 & 7.342 \\
\hline $\mathrm{PA}$ & 143 & 2.713 & 20,64 & 10.415 & 79,25 & 14 & 0,11 & 13.142 \\
\hline $\mathrm{PB}$ & 223 & 1.599 & 18,23 & 7.170 & 81,74 & 3 & 0,03 & 8.772 \\
\hline $\mathrm{PE}$ & 185 & 2.257 & 18,01 & 10.257 & 81,85 & 18 & 0,14 & 12.532 \\
\hline $\mathrm{PI}$ & 222 & 1.199 & 17,17 & 5.777 & 82,71 & 9 & 0,13 & 6.985 \\
\hline $\mathrm{PR}$ & 399 & 4.357 & 17,81 & 20.096 & 82,13 & 17 & 0,07 & 24.470 \\
\hline $\mathrm{RJ}$ & 92 & 3.797 & 21,84 & 13.587 & 78,14 & 3 & 0,02 & 17.387 \\
\hline $\mathrm{RN}$ & 167 & 1.216 & 19,38 & 5.056 & 80,59 & 2 & 0,03 & 6.274 \\
\hline $\mathrm{RO}$ & 52 & 738 & 18,40 & 3.271 & 81,55 & 2 & 0,05 & 4.011 \\
\hline RR & 15 & 239 & 19,95 & 959 & 80,05 & 0 & 0,00 & 1.198 \\
\hline RS & 497 & 4.646 & 18,68 & 20.222 & 81,29 & 9 & 0,04 & 24.877 \\
\hline $\mathrm{SC}$ & 293 & 2.520 & 18,32 & 11.232 & 81,68 & 0 & 0,00 & 13.752 \\
\hline $\mathrm{SE}$ & 75 & 943 & 20,20 & 3.721 & 79,70 & 5 & 0,11 & 4.669 \\
\hline $\mathrm{SP}$ & 645 & 13.315 & 20,07 & 53.037 & 79,93 & 0 & 0,00 & 66.352 \\
\hline TO & 139 & 1.228 & 22,63 & 4.197 & 77,34 & 2 & 0,04 & 5.427 \\
\hline Total & 5.560 & 70.321 & 19,14 & 296.902 & 80,82 & 121 & 0,03 & 367.344 \\
\hline
\end{tabular}


Quadro 2

Candidat@s por partidos/sexo Câmara de Vereadores

\begin{tabular}{|c|c|c|c|c|c|c|c|}
\hline \multirow{2}{*}{$\begin{array}{l}\text { Partidos } \\
\text { Políticos } \\
\end{array}$} & \multicolumn{2}{|c|}{ Mulheres } & \multicolumn{2}{|c|}{ Homens } & \multicolumn{2}{|c|}{ Sexo não informado } & \multirow[t]{2}{*}{ Total } \\
\hline & Quantidade & $\%$ & Quantidade & $\%$ & Quantidade & $\%$ & \\
\hline PAN & 297 & 21,46 & 1.086 & 78,47 & 1 & 0,07 & 1.384 \\
\hline PC do B & 414 & 20,04 & 1.651 & 79,91 & 1 & 0,05 & 2.066 \\
\hline $\mathrm{PCB}$ & 32 & 18,71 & 139 & 81,29 & 0 & 0,00 & 171 \\
\hline $\mathrm{PCO}$ & 10 & 20,83 & 38 & 79,17 & 0 & 0,00 & 48 \\
\hline PDT & 4.555 & 18,82 & 19.642 & 81,14 & 10 & 0,04 & 24.207 \\
\hline PFL & 8.061 & 18,85 & 34.696 & 81,12 & 14 & 0,03 & 42.771 \\
\hline PGT & 302 & 19,97 & 1.209 & 79,96 & 1 & 0,07 & 1.512 \\
\hline PHS & 561 & 19,76 & 2.275 & 80,13 & 3 & 0,11 & 2.839 \\
\hline $\mathrm{PL}$ & 3.657 & 18,30 & 16.321 & 81,67 & 6 & 0,03 & 19.984 \\
\hline PMDB & 9.406 & 18,91 & 40.323 & 81,06 & 14 & 0,03 & 49.743 \\
\hline PMN & 1.005 & 20,20 & 3.969 & 79,78 & 1 & 0,02 & 4.975 \\
\hline $\mathrm{PPB}$ & 6.264 & 18,67 & 27.287 & 81,32 & 4 & 0,01 & 33.555 \\
\hline PPS & 3.805 & 19,22 & 15.977 & 80,70 & 16 & 0,08 & 19.798 \\
\hline PRN & 237 & 20,22 & 935 & 79,78 & 0 & 0,00 & 1,172 \\
\hline PRONA & 282 & 22,17 & 989 & 77,75 & 1 & 0,08 & 1.272 \\
\hline PRP & 902 & 19,52 & 3.717 & 80,45 & 1 & 0,02 & 4.620 \\
\hline PRTB & 557 & 20,12 & 2,211 & 79,85 & 1 & 0,04 & 2.769 \\
\hline PSB & 2.975 & 19,28 & 12.449 & 80,66 & 9 & 0,06 & 15.433 \\
\hline $\mathrm{PSC}$ & 1.605 & 18,71 & 6.972 & 81,28 & 1. & 0,01 & 8.578 \\
\hline PSD & 2.161 & 19,85 & 8.719 & 80,11 & 4 & 0,04 & 10.884 \\
\hline PSDB & 7.299 & 18,82 & 31.469 & 81,15 & 12 & 0,03 & 38.780 \\
\hline PSDC & 735 & 19,65 & 3.005 & 80,33 & 1 & 0,03 & 3.741 \\
\hline PSL & 1.024 & 19,07 & 4.342 & 80,87 & 3 & 0,06 & 5.369 \\
\hline PST & 1.039 & 20,55 & 4.015 & 79,41 & 2 & 0,04 & 5.056 \\
\hline PSTU & 76 & 24,20 & 238 & 75,80 & 0 & 0,00 & 314 \\
\hline $\mathrm{PT}$ & 5.105 & 20,17 & 20.202 & 79.82 & 1 & 0,00 & 25.308 \\
\hline PT do B & 655 & 21,02 & 2.460 & 78,95 & 1 & 0,03 & 3.116 \\
\hline PTB & 5.606 & 18,75 & 24.288 & 81,21 & 12 & 0,04 & 29.906 \\
\hline PTN & 398 & 19,59 & 1.633 & 80,36 & 1 & 0,05 & 2.032 \\
\hline $\mathrm{PV}$ & 1.296 & 21,81 & 4.645 & 78,19 & 0 & 0,00 & 5.941 \\
\hline Total & 70.321 & 19,14 & 296.902 & 80,82 & 121 & 0,03 & 367.344 \\
\hline
\end{tabular}

Fonte: TSE - dados gerados em 03/10/2000 
TRANSFORMANDO A DIFERENÇA: AS MULHERES NA POLÍTICA

Quadro 3

Candidat@s por Unidade da Federação

Prefeituras

\begin{tabular}{|c|c|c|c|c|c|c|c|c|}
\hline \multirow[t]{2}{*}{ UF } & \multirow{2}{*}{\begin{tabular}{|c|c|} 
Municípios \\
2000
\end{tabular}} & \multicolumn{2}{|c|}{ Mulheres } & \multicolumn{2}{|l|}{ Homens } & \multicolumn{2}{|c|}{ Sexo não informado } & \multirow[t]{2}{*}{ Total } \\
\hline & & Quantidade & $\%$ & Quantidade & $\%$ & Quantidade & $\%$ & \\
\hline $\mathrm{AC}$ & 22 & 5 & 9,43 & 48 & 90,57 & 0 & 0,00 & 53 \\
\hline $\mathrm{AL}$ & 102 & 36 & 12,33 & 256 & 87,67 & 0 & 0,00 & 292 \\
\hline $\mathrm{AM}$ & 62 & 6 & 2,79 & 209 & 97,21 & 0 & 0,00 & 215 \\
\hline $\mathrm{AP}$ & 16 & 7 & 10,77 & 58 & 89,23 & 0 & 0,00 & 65 \\
\hline $\mathrm{BA}$ & 417 & 97 & 8,60 & 1.031 & 91,40 & 0 & 0,00 & 1.128 \\
\hline $\mathrm{CE}$ & 184 & 58 & 12,66 & 400 & 87,34 & 0 & 0,00 & 458 \\
\hline ES & 78 & 10 & 4,35 & 219 & 95,22 & 1 & 0,43 & 230 \\
\hline $\mathrm{GO}$ & 246 & 65 & 9,82 & 597 & 90,18 & 0 & 0,00 & 662 \\
\hline $\mathrm{MA}$ & 217 & 73 & 12,13 & 529 & 87,87 & 0 & 0,00 & 602 \\
\hline $\mathrm{MG}$ & 853 & 128 & 5,73 & 2.103 & 94,22 & 1 & 0,04 & 2.232 \\
\hline $\mathrm{MS}$ & 77 & 21 & 9,42 & 202 & 90,58 & 0 & 0,00 & 223 \\
\hline $\mathrm{MT}$ & 139 & 21 & 5,90 & 335 & 94,10 & 0 & 0,00 & 356 \\
\hline $\mathrm{PA}$ & 143 & 43 & 9,41 & 413 & 90,37 & 1 & 0,22 & 457 \\
\hline $\mathrm{PB}$ & 223 & 51 & 10,10 & 454 & 89,90 & 0 & 0,00 & 505 \\
\hline $\mathrm{PE}$ & 185 & 31 & 6,35 & 457 & 93,65 & 0 & 0,00 & 488 \\
\hline PI & 222 & 53 & 10,13 & 470 & 89,87 & 0 & 0,00 & 523 \\
\hline PR & 399 & 53 & 5,28 & 950 & 94,72 & 0 & 0,00 & 1.003 \\
\hline $\mathrm{RJ}$ & 92 & 31 & 9,39 & 299 & 90,61 & 0 & 0,00 & 330 \\
\hline $\mathrm{RN}$ & 167 & 44 & 10,71 & 366 & 89,05 & 1 & 0,24 & 411 \\
\hline $\mathrm{RO}$ & 52 & 21 & 12,00 & 154 & 88,00 & 0 & 0,00 & 175 \\
\hline RR & 15 & 4 & 10,81 & 33 & 89,19 & 0 & 0,00 & 37 \\
\hline $\mathrm{RS}$ & 497 & 58 & 4,36 & 1.272 & 95,64 & 0 & 0,00 & 1.330 \\
\hline $\mathrm{SC}$ & 293 & 40 & 5,38 & 703 & 94,62 & 0 & 0,00 & 743 \\
\hline $\mathrm{SE}$ & 75 & 13 & 6,44 & 189 & 93,56 & 0 & 0,00 & 202 \\
\hline $\mathrm{SP}$ & 645 & 137 & 7,01 & 1.816 & 92,99 & 0 & 0,00 & 1.953 \\
\hline $\mathrm{TO}$ & 139 & 33 & 9,62 & 310 & 90,38 & 0 & 0,00 & 343 \\
\hline Total & 5.560 & 1.139 & 7,59 & 13.873 & 92,39 & 4 & $\mathbf{0 , 0 3}$ & 15.016 \\
\hline
\end{tabular}




\section{Quadro 4 \\ Candidat@s por partido \\ Prefeituras}

\begin{tabular}{|c|c|c|c|c|c|c|c|}
\hline \multirow{2}{*}{$\begin{array}{l}\text { Partidos } \\
\text { Políticos }\end{array}$} & \multicolumn{2}{|c|}{ Mulheres } & \multicolumn{2}{|c|}{ Homens } & \multicolumn{2}{|c|}{ Sexo não informado } & \multirow[t]{2}{*}{ Total } \\
\hline & Quantidade & $\%$ & Quantidade & $\%$ & Quantidade & $\%$ & \\
\hline PAN & 1 & 4,00 & 24 & 96,00 & 0 & 0,00 & 25 \\
\hline $\mathrm{PC}$ do $\mathrm{B}$ & 5 & 17,86 & 23 & 82,14 & 0 & 0,00 & 28 \\
\hline PCB & 1 & 25,00 & 3 & 75,00 & 0 & 0,00 & 4 \\
\hline $\mathrm{PCO}$ & 2 & 16,67 & 10 & 83,33 & 0 & 0,00 & 12 \\
\hline PDT & 49 & 5,43 & 853 & 94,46 & 1 & 0,11 & 903 \\
\hline PFL & 171 & 7,44 & 2.127 & 92,52 & 1 & 0,04 & 2.299 \\
\hline $\mathrm{PGT}$ & 0 & 0,00 & 14 & 100,00 & 0 & 0,00 & 14 \\
\hline PHS & 4 & 7,55 & 49 & 92,45 & 0 & 0,00 & 53 \\
\hline $\mathrm{PL}$ & 36 & 5,95 & 569 & 94,05 & 0 & 0,00 & 605 \\
\hline PMDB & 195 & 6,86 & 2.647 & 93,14 & 0 & 0,00 & 2.842 \\
\hline PMN & 5 & 6,25 & 75 & 93,75 & 0 & 0,00 & 80 \\
\hline PPB & 81 & 5,74 & 1.328 & 94,18 & 1 & 0,07 & 1.410 \\
\hline PPS & 53 & 8,39 & 579 & 91,61 & 0 & 0,00 & 632 \\
\hline PRN & 0 & 0,00 & 32 & 100,00 & 0 & 0,00 & 32 \\
\hline PRONA & 0 & 0,00 & 15 & 100,00 & 0 & 0,00 & 15 \\
\hline PRP & 10 & 12,82 & 68 & 87,18 & 0 & 0,00 & 78 \\
\hline PRTB & 3 & 5,66 & 50 & 94,34 & 0 & 0,00 & 53 \\
\hline PSB & 42 & 8,71 & 440 & 91,29 & 0 & 0,00 & 482 \\
\hline $\mathrm{PSC}$ & 21 & 12,35 & 149 & 87,65 & 0 & 0,00 & 170 \\
\hline PSD & 27 & 8,79 & 280 & 91,21 & 0 & 0,00 & 307 \\
\hline PSDB & 148 & 7,12 & 1.931 & 92,84 & 1 & 0,05 & 2.080 \\
\hline PSDC & 9 & 13,43 & 58 & 86,57 & 0 & 0,00 & 67 \\
\hline PSL & 5 & 5,00 & 95 & 95,00 & 0 & 0,00 & 100 \\
\hline $\mathrm{PST}$ & 2 & 2,56 & 76 & 97,44 & 0 & 0,00 & 78 \\
\hline PSTU & 8 & 16,67 & 40 & 83,33 & 0 & 0,00 & 48 \\
\hline $\mathrm{PT}$ & 161 & 12,23 & 1.155 & 87,77 & 0 & 0,00 & 1.316 \\
\hline PT do B & 5 & 10,42 & 43 & 89,58 & 0 & 0,00 & 48 \\
\hline PTB & 83 & 7,72 & 992 & 92,28 & 0 & 0,00 & 1.075 \\
\hline PTN & 0 & 0,00 & 24 & 100,00 & 0 & 0,00 & 24 \\
\hline $\mathrm{PV}$ & 12 & 8,82 & 124 & 91,18 & 0 & 0,00 & 136 \\
\hline Total & 1.139 & 7,59 & 13.873 & 92,39 & 4 & 0,03 & 15.016 \\
\hline
\end{tabular}


TRANSFORMANDO A DIFERENÇA: AS MULHERES NA POLÍTICA

Quadro 5

Eleição para Câmara de Vereadores

\begin{tabular}{|c|c|c|c|c|c|c|c|c|}
\hline \multirow[t]{2}{*}{ UF } & \multirow{2}{*}{\begin{tabular}{|c} 
Municípios \\
2000 \\
\end{tabular}} & \multicolumn{2}{|c|}{ Mulheres } & \multicolumn{2}{|c|}{ Homens } & \multicolumn{2}{|c|}{ Sexo não informado } & \multirow[t]{2}{*}{ Total } \\
\hline & & Quantidade & $\%$ & Quantidade & $\%$ & Quantidade & $\%$ & \\
\hline $\mathrm{AC}$ & 22 & 30 & 14,35 & 179 & 85,65 & 0 & 0,00 & 209 \\
\hline $\mathrm{AL}$ & 102 & 131 & 12,91 & 884 & 87,09 & 0 & 0,00 & 1.015 \\
\hline $\mathrm{AM}$ & 62 & 82 & 13,02 & 548 & 86,98 & 0 & 0,00 & 630 \\
\hline $\mathrm{AP}$ & 16 & 33 & 20,63 & 127 & 79,38 & 0 & 0,00 & 160 \\
\hline $\mathrm{BA}$ & 417 & 571 & 12,14 & 4.128 & 87,77 & 4 & 0,09 & 4.703 \\
\hline $\mathrm{CE}$ & 184 & 319 & 12,74 & 2.185 & 87,26 & 0 & 0,00 & 2.504 \\
\hline ES & 78 & 78 & 7,85 & 916 & 92,15 & 0 & 0,00 & 994 \\
\hline GO & 246 & 305 & 12,37 & 2.161 & 87,63 & 0 & 0,00 & 2.466 \\
\hline $\mathrm{MA}$ & 217 & 339 & 14,51 & 1.996 & 85,45 & 1 & 0,04 & 2.336 \\
\hline $\mathrm{MG}$ & 853 & 958 & 10,54 & 8.133 & 89,44 & 2 & 0,02 & 9.093 \\
\hline MS & 77 & 102 & 12,96 & 685 & 87,04 & 0 & 0,00 & 787 \\
\hline MT & 139 & 196 & 13,86 & 1.217 & 86,07 & 1 & 0,07 & 1.414 \\
\hline $\mathrm{PA}$ & 143 & 211 & 13,64 & 1.334 & 86,23 & 2 & 0,13 & 1.547 \\
\hline PB & 223 & 352 & 14,10 & 2.145 & 85,90 & 0 & 0,00 & 2.497 \\
\hline $\mathrm{PE}$ & 185 & 197 & 9,95 & 1.781 & 89,95 & 2 & 0,10 & 1.980 \\
\hline PI & 222 & 268 & 12,63 & 1.851 & 87,23 & 3 & 0,14 & 2.122 \\
\hline PR & 399 & 409 & 10,21 & 3.597 & 89,77 & 1. & 0,02 & 4.007 \\
\hline $\mathrm{RJ}$ & 92 & 93 & 7,27 & 1.186 & 92,73 & 0 & 0,00 & 1.279 \\
\hline $\mathrm{RN}$ & 167 & 254 & 15,50 & 1.385 & 84,50 & 0 & 0,00 & 1.639 \\
\hline $\mathrm{RO}$ & 52 & 55 & 10,44 & 471 & 89,37 & 1 & 0,19 & 527 \\
\hline$R R$ & 15 & 16 & 10,13 & 142 & 89,87 & 0 & 0,00 & 158 \\
\hline RS & 497 & 539 & 10,54 & 4.572 & 89,42 & 2 & 0,04 & 5.113 \\
\hline $\mathrm{SC}$ & 293 & 292 & 9,76 & 2.701 & 90,24 & 0 & 0,00 & 2.993 \\
\hline $\mathrm{SE}$ & 75 & 137 & 17,00 & 669 & 83,00 & 0 & 0,00 & 806 \\
\hline $\mathrm{SP}$ & 645 & 828 & 10,33 & 7.189 & 89,67 & 0 & 0,00 & 8.017 \\
\hline $\mathrm{TO}$ & 139 & 197 & 15,52 & 1.071 & 84,40 & 1 & 0,08 & 1.269 \\
\hline Total & 5.560 & 6.992 & 11,60 & \begin{tabular}{|l|}
53.253 \\
\end{tabular} & 88,36 & 20 & 0,03 & 60.265 \\
\hline
\end{tabular}


Quadro 6

Eleit@s por partidos/sexo - 2000 Câmara de Vereadores

\begin{tabular}{|c|c|c|c|c|c|c|c|}
\hline \multicolumn{8}{|c|}{ CÁMARA DE VEREADORES } \\
\hline \multicolumn{8}{|c|}{ ELEIT@S POR PARTIDO/SEXO - ELEICÕES 2000 } \\
\hline \multirow{2}{*}{\begin{tabular}{|l} 
Partidos \\
Políticos
\end{tabular}} & \multicolumn{2}{|c|}{ Mulheres } & \multicolumn{2}{|c|}{ Homens } & \multicolumn{2}{|c|}{ Sexo não informado } & \multirow[t]{2}{*}{ Total } \\
\hline & Quantidade & $\%$ & Quantidade & $\%$ & Quantidade & $\%$ & \\
\hline PAN & 2 & 6,45 & 29 & 93,55 & 0 & 0,00 & 31 \\
\hline $\mathrm{PC}$ do B & 20 & 13,42 & 128 & 85,91 & 1 & 0,67 & 149 \\
\hline $\mathrm{PCB}$ & 0 & 0,00 & 1 & 100,00 & 0 & 0,00 & 1 \\
\hline $\mathrm{PCO}$ & 0 & & 0 & & 0 & -1 & 0 \\
\hline PDT & 372 & 9,88 & 3.393 & 90,10 & 1 & 0,03 & 3.766 \\
\hline PFL & 1.164 & 12,07 & 8.475 & 87,90 & 3 & 0,03 & 9.642 \\
\hline PGT & 3 & 11,54 & 23 & 88,46 & 0 & 0,00 & 26 \\
\hline PHS & 12 & 9,09 & 120 & 90,91 & 0 & 0,00 & 132 \\
\hline $\mathrm{PL}$ & 322 & 11,13 & 2.570 & 88,80 & 2 & 0,07 & 2.894 \\
\hline PMDB & 1.329 & 11,70 & 10.030 & 88,27 & 4 & 0,04 & 11.363 \\
\hline PMN & 41 & 10,62 & 344 & 89,12 & i) & 0,26 & 386 \\
\hline PPB & 837 & 11,86 & 6.221 & 88,12 & 2 & 0,03 & 7.060 \\
\hline PPS & 284 & 11,05 & 2.284 & 88,91 & 1 & 0,04 & 2.569 \\
\hline PRN & 6 & 9,84 & 55 & 90,16 & 0 & 0,00 & 61 \\
\hline PRONA & 5 & 16,67 & 25 & 83,33 & 0 & 0,00 & 30 \\
\hline PRP & 42 & 11,35 & 328 & 88,65 & 0 & 0,00 & 370 \\
\hline PRTB & 19 & 11,52 & 146 & 88,48 & 0 & 0,00 & 165 \\
\hline PSB & 194 & 11,27 & 1.526 & 88,67 & 1 & 0,06 & 1.721 \\
\hline PSC & 60 & 8,17 & 674 & 91,83 & 0 & 0,00 & 734 \\
\hline PSD & 171 & 11,66 & 1.295 & 88,34 & 0 & 0,00 & 1.466 \\
\hline PSDB & 1.006 & 11,82 & 7.505 & 88,15 & 3 & 0,04 & 8.514 \\
\hline PSDC & 19 & 7,82 & 224 & 92,18 & 0 & 0,00 & 243 \\
\hline PSL & 43 & 8,83 & 444 & 91,17 & 0 & 0,00 & 487 \\
\hline PST & 54 & 13,24 & 354 & 86,76 & 0 & 0,00 & 408 \\
\hline PSTU & 0 & 0,00 & 3 & 100,00 & 0 & 0,00 & 3 \\
\hline PT & 349 & 14,06 & 2.134 & 85,94 & 0 & 0,00 & 2.483 \\
\hline PT do B & 20 & 11,36 & 156 & 88,64 & 0 & 0,00 & 176 \\
\hline PTB & 581 & 11,65 & 4.406 & 88,33 & 1) & 0,02 & 4.988 \\
\hline PTN & 7 & 8,54 & 75 & 91,46 & 0 & 0,00 & 82 \\
\hline $\mathrm{PV}$ & 30 & 9,52 & 285 & 90,48 & 0 & 0,00 & 315 \\
\hline Total & 6.992 & 11,60 & 53.253 & 88,36 & 20 & 0,03 & 60.265 \\
\hline
\end{tabular}


TRANSFORMANDO A DIFERENÇA: AS MULHERES NA POLÍTICA

Quadro 7

Eleitas por UF/sexo - 2000

Prefeituras Municipais

\begin{tabular}{|c|c|c|c|c|c|c|c|c|}
\hline \multirow[t]{2}{*}{ UF } & \multirow{2}{*}{$\begin{array}{c}\text { Municípios } \\
2000\end{array}$} & \multicolumn{2}{|c|}{\begin{tabular}{|l} 
Mulheres \\
\end{tabular}} & \multicolumn{2}{|c|}{ Homens } & \multicolumn{2}{|c|}{ Sexo não informado } & \multirow[t]{2}{*}{ Total } \\
\hline & & Quantidade & $\%$ & Quantidade & $\%$ & Quantidade & $\%$ & \\
\hline $\mathrm{AC}$ & 22 & 1 & 4,55 & 21 & 95,45 & 0 & 0,00 & 22 \\
\hline $\mathrm{AL}$ & 102 & 13 & 12,75 & 89 & 87,25 & 0 & 0,00 & 102 \\
\hline $\mathrm{AM}$ & 62 & 2 & 3,23 & 60 & 96,77 & 0 & 0,00 & 62 \\
\hline AP & 16 & 1 & 6,25 & 15 & 93,75 & 0 & 0,00 & 16 \\
\hline BA & 417 & 25 & 6,00 & 392 & 94,00 & 0 & 0,00 & 417 \\
\hline $\mathrm{CE}$ & 184 & 22 & 11,96 & 162 & 88,04 & 0 & 0,00 & 184 \\
\hline ES & 78 & 1 & 1,28 & 76 & 97,44 & 1 & 1,28 & 78 \\
\hline $\mathrm{GO}$ & 246 & 20 & 8,13 & 226 & 91,87 & 0 & 0,00 & 246 \\
\hline $\mathrm{MA}$ & 217 & 19 & 8,80 & 197 & 91,20 & 0 & 0,00 & 216 \\
\hline $\mathrm{MG}$ & 853 & 41 & 4,81 & 812 & 95,19 & 0 & 0,00 & 853 \\
\hline MS & 77 & 5 & 6,49 & 72 & 93,51 & 0 & 0,00 & 77 \\
\hline MT & 139 & 7 & 5,04 & 132 & 94,96 & 0 & 0,00 & 139 \\
\hline $\mathrm{PA}$ & 143 & 11 & 7,69 & 132 & 92,31 & 0 & 0,00 & 143 \\
\hline $\mathrm{PB}$ & 223 & 17 & 7,62 & 206 & 92,38 & 0 & 0,00 & 223 \\
\hline $\mathrm{PE}$ & 185 & 14 & 7,61 & 170 & 92,39 & 0 & 0,00 & 184 \\
\hline $\mathrm{PI}$ & 222 & 22 & 9,91 & 200 & 90,09 & 0 & 0,00 & 222 \\
\hline PR & 399 & 19 & 4,76 & 380 & 95,24 & 0 & 0,00 & 399 \\
\hline RJ & 92 & 4 & 4,35 & 88 & 95,65 & 0 & 0,00 & 92 \\
\hline RN & 167 & 11 & 6,59 & 156 & 93,41 & 0 & 0,00 & 167 \\
\hline $\mathrm{RO}$ & 52 & 4 & 7,69 & 48 & 92,31 & 0 & 0,00 & 52 \\
\hline RR & 15 & 3 & 20,00 & 12 & 80,00 & 0 & 0,00 & 15 \\
\hline RS & 497 & 9 & 1,81 & 488 & 98,19 & 0 & 0,00 & 497 \\
\hline $\mathrm{SC}$ & 293 & 5 & 1,71 & 288 & 98,29 & 0 & 0,00 & 293 \\
\hline $\mathrm{SE}$ & 75 & 6 & 8,00 & 69 & 92,00 & 0 & 0,00 & 75 \\
\hline $\mathrm{SP}$ & 645 & 24 & 3,72 & 621 & 96,28 & 0 & 0,00 & 645 \\
\hline TO & 139 & 12 & 8,63 & 127 & 91,37 & 0 & 0,00 & 139 \\
\hline Total & 5.560 & 318 & 5,72 & 5.239 & 94,26 & 1 & 0,02 & 5.558 \\
\hline
\end{tabular}




\section{Quadro 8 \\ Eleit@s por partidos/sexo - 2000 Prefeituras Municipais}

\begin{tabular}{|c|c|c|c|c|c|c|c|}
\hline \multirow{2}{*}{$\begin{array}{l}\text { Partıdos } \\
\text { Políticos }\end{array}$} & \multicolumn{2}{|c|}{ Mulheres } & \multicolumn{2}{|c|}{ Homens } & \multicolumn{2}{|c|}{ Sexo não informado } & \multirow[t]{2}{*}{ Total } \\
\hline & Quantidade & $\%$ & Quantidade & $\%$ & Quantidade & $\%$ & \\
\hline PAN & 0 & 0,00 & 1 & 100,00 & 0 & 0,00 & 1 \\
\hline $\mathrm{PC}$ do $\mathrm{B}$ & 1 & 100,00 & 0 & - & 0 & -1 & 1 \\
\hline $\mathrm{PCB}$ & 0 & & 0. & -1 & 0 & - & 0 \\
\hline $\mathrm{PCO}$ & 0 & & 0 & - & 0 & - & 0 \\
\hline PDT & 6 & 2,08 & 282 & 97,92 & 0 & 0,00 & 288 \\
\hline PFL & 75 & 7,31 & 951 & 92,69 & 0 & 0,00 & 1.026 \\
\hline $\mathrm{PGT}$ & 0 & - & 0 & -1 & 0 & - & 0 \\
\hline $\mathrm{PHS}$ & 0 & 0,00 & 6 & 100,00 & 0 & 0,00 & 6 \\
\hline $\mathrm{PL}$ & 9 & 3,85 & 225 & 96,15 & 0 & 0,00 & 234 \\
\hline PMDB & 60 & 4,77 & 1.198 & 95,23 & 0 & 0,00 & 1.258 \\
\hline $\mathrm{PMN}$ & 0 & 0,00 & 14 & 100,00 & 0 & 0,00 & 14 \\
\hline PPB & 32 & 5,18 & 586 & 94,82 & 0 & 0,00 & 618 \\
\hline PPS & 11 & 6,67 & 154 & 93,33 & 0 & 0,00 & 165 \\
\hline PRN & 0 & 0,00 & 3 & 100,00 & 0 & 0,00 & 3 \\
\hline PRONA & 0 & -1 & 0 & - & 0 & - & 0 \\
\hline PRP & 3 & 18,75 & 13 & 81,25 & 0 & 0,00 & 16 \\
\hline PRTB & 0 & 0,00 & 4 & 100,00 & 0 & 0,00 & 4 \\
\hline PSB & 13 & 9,77 & 120 & 90,23 & 0 & 0,00 & 133 \\
\hline PSC & 3 & 9,09 & 30 & 90,91 & 0 & 0,00 & 33 \\
\hline PSD & 10 & 9,01 & 101 & 90,99 & 0 & 0,00 & 111 \\
\hline PSDB & 58 & 5,86 & 931 & 94,04 & 1 & 0,10 & 990 \\
\hline PSDC & 0 & 0,00 & 8 & 100,00 & 0 & 0,00 & 8 \\
\hline $\mathrm{PSL}$ & 0 & 0,00 & 26 & 100,00 & 0 & 0,00 & 26 \\
\hline PST & 14 & 6,25 & 15 & 93,75 & 0 & 0,00 & 16 \\
\hline PSTU & 0 & -1 & 0 & -1 & 0 & - & 0 \\
\hline PT & 9 & 4,81 & 178 & 95,19 & 0 & 0,00 & 187 \\
\hline PT do B & I] & 16,67 & 5 & 83,33 & 0 & 0,00 & 6 \\
\hline PTB & 25 & 6,28 & 373 & 93,72 & 0 & 0,00 & 398 \\
\hline PTN & 0 & 0,00 & 2 & 100,00 & 0 & 0,00 & 2 \\
\hline $\mathrm{PV}$ & 1 & 7,69 & 12 & 92,31 & 0 & 0,00 & 13 \\
\hline Total & 318 & 5,72 & 5.238 & 94,26 & 1) & 0,02 & 5.557 \\
\hline
\end{tabular}




\section{ANEXO II DEPUTADAS E VEREADORAS PARTICIPANTES DO SEMINÁRIO}

Deputada Federal Jandira Feghali - PC do B/RJ

Médica, está no terceiro mandato na Câmara dos Deputados. Preocupada com a defesa dos interesses dos trabalhadores e das mulheres, integra a bancada de saúde da Câmara. Defende a Previdência Social pública. Iniciou a militância política quando era estudante de medicina. Atua firmemente na defesa dos direitos da mulher no Congresso Nacional. Integra o Conselho Consultivo do Programa Direitos da Mulher na Lei e na Vida, do CFEMEA. É membro de várias comissões na Câmara.

Prefeita Wilma Maria de Faria Meira - PSB - Natal/RN

Nascida em Mossoró/RN. Professora Universitária, do Departamento de Educação do Centro de Ciências Sociais Aplicadas da UFRN. Exerceu os cargos de: Assessora Técnica - Secretaria de Educação de Natal; Coordenadora de Projetos e Convênios da UFRN; Coordenadora do Programa PRONAV; Secretária do TrabaIho e Bem-Estar Social e Presidente da Fundação Estadual do Trabalho e Ação Comunitária; Presidente do Conselho de Menores da FEBEM; Presidente do Conselho da COHAB/RN. Foi eleita Deputada Federal Constituinte/1986, Prefeita de Natal/1989, Presidente do Instituto Clara Camarão/1993 e Presidente Estadual do PSB/1994 a 1997. É Prefeita de Natal desde 1997, tendo sido reeleita em 2000.

Vereadora Eni Fernandes - PT/São José do Rio Preto/SP

Assistente Social, formada pela Faculdade de Serviço Social de Lins/SP, com especialização em organização e desenvolvimento de comunidade. Destaca-se na defesa de moradia para os favelados e na defesa dos direitos das mulheres. Foi eleita vereadora em 1996, sendo a única mulher na Câmara Municipal de São José do Rio Preto/SP. É a primeira mulher negra a ocupar uma cadeira na Câmara de Vereadores de São José do Rio Preto. Foi reeleita em 2000.

Deputada Federal Miriam Reid - PDT/RJ

É professora pública e assistente social e iniciou sua vida política em Macaé, Rio de Janeiro, onde nasceu, sendo eleita vereadora por duas vezes. É evangélica e ingressou na vida política militando no Movimento Estudantil. Tem-se destacado na defesa do ensino público e na valorização do magistério e da soberania nacional. Foi Deputada Estadual na Assembléia Legislativa do Rio de Janeiro. Assume pela primeira vez um mandato na Câmara Federal em 1999. 
Deputada Distrital Lúcia Carvalho - PT/DF

Nascida em Londrina/PR. Professora e pedagoga. Ajudou a fundar a Associação dos Professores do Distrito Federal e as Associações de moradores da Ceilândia e União e Luta do PT-Sul. Participou da construção do Partido dos Trabalhadores e da Central Única dos Trabalhadores. Foi presidente do Sindicato dos Professores no DF e Secretária Geral da Confederação Nacional dos TrabaIhadores em Educação 1989/1990. Foi Membro da direção nacional da CUT e da Executiva Nacional do PT. Está no segundo mandato como Deputada Distrital. Titular da Secretaria de Mulheres da União Nacional dos Legislativos Estaduais UNALE.

Deputada Estadual Célia Leão - PSDB/SP

Advogada, elegeu-se vereadora em 1988 em Campinas/SP, sendo a mais votada. Em 1990, foi a primeira e única mulher eleita deputada estadual pelo PSDB, sendo reeleita em 1994 e 1998. Atualmente é vice-líder do PSDB na Assembléia Legislativa e presidente da Comissão de Constituição e Justiça naquela casa. É militante ativa dos movimentos pelos direitos de pessoas portadoras de deficiências desde 1980.

Deputada Federal Maria Elvira - PMDB/MG

Empresária e jornalista, ałua há mais de dez anos no Movimento de Mulheres, em Minas Gerais. Chegou à Câmara Federal depois de ter cumprido dois mandatos consecutivos como Deputada Estadual - 1987 a 1990 e 1991 a 1994. Assume o seu segundo mandato na Câmara Federal. Foi a mais votada do PMDB de Minas Gerais. Fundou a Frente Parlamentar de Valorização do Idoso e participou de várias comissões. Filiada ao PMDB desde 1985, alcançou a vice-presidência regional da legenda em 1989.

Deputada Federal Alcione Athayde - PPB/RJ

Médica, carioca. Assumiu o mandato de Deputada Federal na legislatura 1995/1999 e novamente na atual legislatura. Foi vice-líder do PPB, em 1997. Foi Secretária Municipal de Saúde de Campos, Rio de Janeiro, no período de 1989 a 1992.

Senadora Telma Slquelra Campos - PPB-TO

Formada em Odontologia, com pós-graduação em Saúde Pública e Odontopediatria. Foi Secretária Municipal de Desenvolvimento Comunitário de Palmas, em 1999, e Secretária Estadual do Trabalho e Ação Social do Governo de Tocantins, em 1998. Exerceu o mandato de senadora de março a junho de 2000. 
Deputada Federal lara Bernardi - PT-SP

Nascida em Sorocaba-SP, professora, sindicalista, atuou como vereadora (PT) em três mandatos. Desde 1978, participa de lutas sociais e políticas. Foi membro do Comitê Brasileiro de Anistia. Na política, sempre se destacou na apresentação de projetos voltados para a área social. Relativamente aos direitos da mulher, foi membro do Conselho Municipal dos Direitos da Mulher, em Sorocaba, e foi autora do projeto que criou o albergue para a mulher vítima de violência.

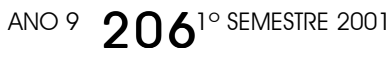

